(2) norden 



\section{Ekonomiska utsikter i Norden 2007}

Nordiska konjunkturgruppens redogörelse hösten 2006 
Ekonomiska utsikter i Norden 2007

Nordiska konjunkturgruppens redogörelse hösten 2006

TemaNord 2006:603

(C) Nordiska ministerrådet, Köpenhamn 2006

ISBN 978-92-893-1582-1

Tryck: Ekspressen Tryk \& Kopicenter. Only available as pirnt-on-demand

Tryckt på miljövänligt papper som uppfyller kraven i den nordiska miljösvanemärkningen.

Publikationen kan beställas på www.norden.org/order. Fler publikationer på

www.norden.org/publikationer

Printed in Denmark

Nordiska ministerrådet

Store Strandstræde 18

DK-1255 Köpenhamn K

Telefon $(+45) 33960200$

Fax (+45) 33960202

www.norden.org

\section{Nordiska rådet}

Store Strandstræde 18

DK-1255 Köpenhamn K

Telefon (+45) 33960400

Fax (+45) 33111870

\section{Det nordiska samarbetet}

Det nordiska samarbetet är ett av världens mest omfattande regionala samarbeten. Det omfattar Danmark, Finland, Island, Norge och Sverige samt de självstyrande områdena Färöarna, Grönland och Åland.

Det nordiska samarbetet är politiskt, ekonomiskt och kulturellt förankrat och är en viktig partner i europeiskt och internationellt samarbete. Den nordiska gemenskapen arbetar för ett starkt Norden i ett starkt Europa.

Det nordiska samarbetet vill styrka nordiska och regionala intressen och värderingar i en global omvärld. Gemensamma värderingar länderna emellan bidrar till att stärka Nordens ställning som en av världens mest innovativa och konkurrenskraftiga regioner. 


\section{Innehåll}

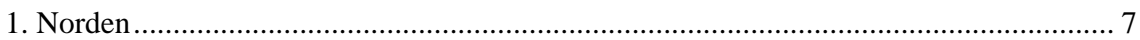

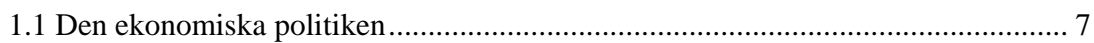

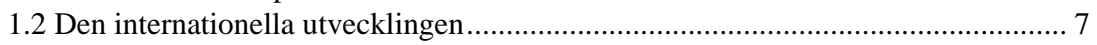

1.3 Den ekonomiska utvecklingen i Norden............................................................... 9

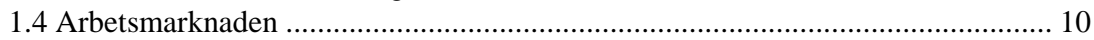

1.5 Penningpolitiken och pris- och kostnadsutvecklingen.......................................... 11

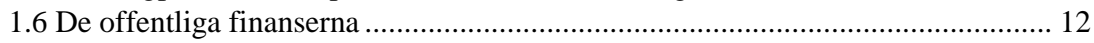

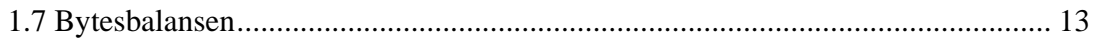

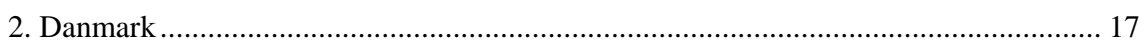

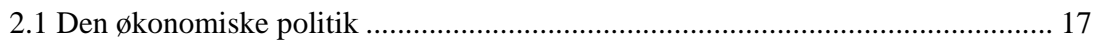

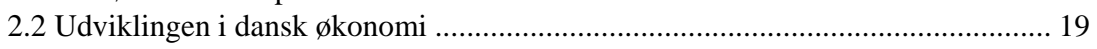

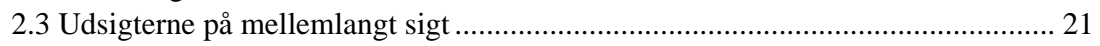

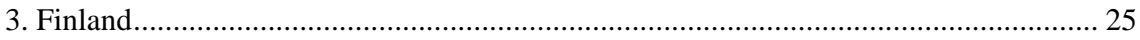

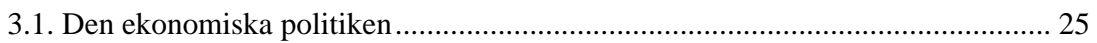

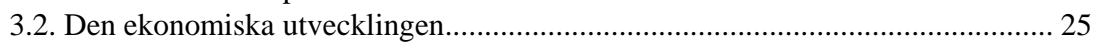

3.3. Utsikterna på medellång sikt ............................................................................. 27

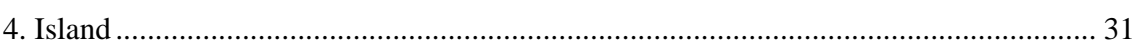

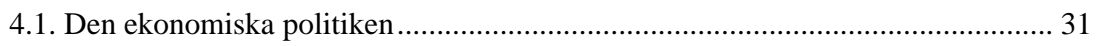

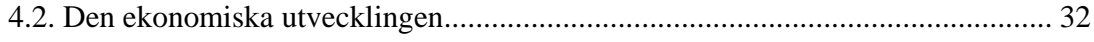

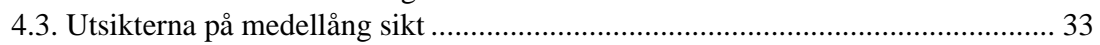

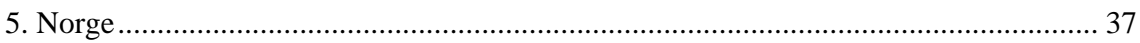

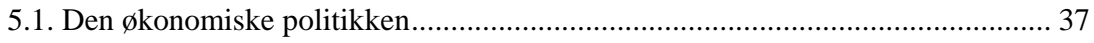

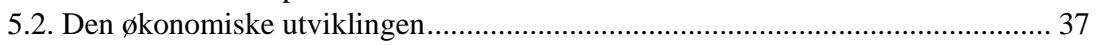

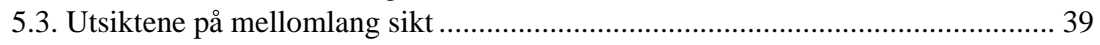

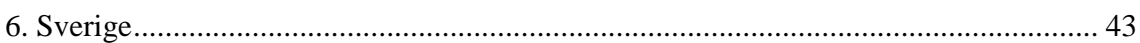

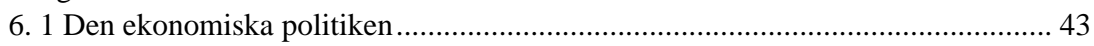

6. 2 Den ekonomiska utvecklingen......................................................................... 44

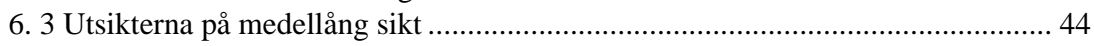





\section{Norden}

\subsection{Den ekonomiska politiken}

Gemensamma mål för den ekonomiska politiken i de nordiska länderna är hög och hållbar ekonomisk tillväxt, hög sysselsättning och prisstabilitet. En grundläggande förutsättning för att uppnå dessa mål är en väl avvägd makroekonomisk politik baserad på sunda offentliga finanser.

Generellt sett befinner sig de nordiska ekonomierna i ett gynnsamt läge jämfört med euroområdet, se diagram 1.1-1.4.

Den demografiska utvecklingen, med en påtagligt ökande andel äldre i befolkningen under det närmaste halvseklet, ställer ökade krav på sunda offentliga finanser i dagsläget. För att kunna bibehålla en väl utvecklad ekonomisk välfärd i framtiden krävs ett högt sparande i den offentliga sektorn under de kommande åren och ansträngningar för att öka antalet personer i arbete.

\subsection{Den internationella utvecklingen}

I år väntas BNP i världen för tredje året i rad växa med närmare $5 \%$, vilket är betydligt starkare än den genomsnittliga tillväxten under de senaste tio åren på omkring $4 \%$. En i tiden sammanfallande hög tillväxt i de viktigaste regionerna i världsekonomin utgör en av förklaringarna till den starka och relativt utdragna internationella högkonjunkturen under senare år. Den globala konjunkturuppgången har i hög grad drivits av en stark investeringsuppgång. Styrkan i världsekonomin väntas dock gradvis avta under slutet av innevarande år och under 2007 i takt med att lediga resurser tas $\mathrm{i}$ anspråk och den penningpolitiska stimulansen ebbar ut. Global tillväxt väntas framöver i mindre uträckning drivas av en stark investerings- och industrikonjunktur och i ökad grad av en ökande konsumtion. I Förenta staterna är konjunkturavmattningen redan synlig. Tillväxten i euroområdet och Asien förutses dock vara god även under nästa år, vilket delvis kompenserar för det amerikanska efterfrågebortfallet. Sammantaget väntas global tillväxt överstiga det historiska genomsnittet både i år och nästa år.

Oljepriset steg till nya rekordnivåer under sommaren. Brentoljan noterades som högst till nära 80 dollar per fat i början på augusti. Utbudet av råolja förväntas dock växa snabbare än efterfrågan under de närmaste åren. Reservkapaciteten kommer därmed att öka och kapacitetstillväxten förutses efterhand pressa oljepriset nedåt. Prisnedgången begränsas dock av en fortsatt geopolitisk oro, risk för framtida produktionsstörningar och 
ökade kostnader för oljeutvinning. Sammantaget väntas oljepriset falla 2007 jämfört med 2006. Osäkerheten i bedömningen av oljepriset är fortsatt stor. Det finns en risk för att oljepriset stiger kraftigt till följd av geopolitisk oro. Även om de senaste två årens oljeprisökningar har haft en begränsad effekt på den realekonomiska utvecklingen kan ytterligare oljeprisökningar leda till att inflationsförväntningarna stiger och att de indirekta effekterna av ett högt oljepris tilltar. Detta skulle i sin tur leda till höjda räntor, vilket riskerar att dämpa konjunkturen i ett läge med redan vikande efterfrågan.

Trots stigande energipriser och krympande lediga resurser har den underliggande inflationen i OECD-området under senare år varit låg. Flera faktorer har haft en dämpande inverkan på prisutvecklingen, vilket gett utrymme för centralbankerna att föra en klart expansiv penningpolitik. En ökad globalisering har inneburit att konkurrensen hårdnat, produktiviteten förbättrats och löneökningstakten dämpats. Därutöver har centralbankernas trovärdighet att verka för stabila priser gradvis ökat under det senaste decenniet. Under senare tid har flera tongivande centralbanker stramat åt penningpolitiken i ljuset av stigande inflationsförväntningar och tilltagande inflation. Flertalet centralbanker har i ökad utsträckning i sina penningpolitiska beslut, utöver strävan att uppnå inflationsmålen, vägt in riskerna med en kraftigt stigande kreditexpansion och betydande prisökningar på bostadsmarknaden.

Efter tre år av stark tillväxt visar den amerikanska ekonomin tydliga tecken på att bromsa in. Den numera något åtstramande penningpolitiken har ännu inte fått fullt genomslag på tillväxten. En förväntad hygglig löneutveckling motverkas av att husprisuppgången dämpas ytterligare i kombination med att fortsatt förhållandevis höga olje- och bensinpriser minskar konsumtionsutrymmet. Inbromsningen på fastighetsmarknaden har dessutom intensifierats, vilket dämpar tillväxten främst under nästa år.

I euroområdet stärktes BNP-tillväxten betydligt under första halvan av 2006. I huvudsak drevs tillväxten av en fortsatt stark investeringskonjunktur och en tilltagande konsumtion hos hushållen. Hushållens konsumtion stimuleras av en stigande sysselsättning och ett tydligt fall i arbetslösheten. Flera tecken tyder dock på att konjunkturen i euroområdet mattas under främst nästa år. En svagare global efterfrågan i kombination med en starkare valuta och en stramare penningpolitik väntas försämra exportutsikterna och dämpa investeringstillväxten.

Asien är den region som har vuxit snabbast under de senaste åren. BNP-tillväxten under perioden 2001-2005 uppgår till 6,2 \% i genomsnitt. En stor del i detta har Kina och Indien som under många år har varit de två stora dragloken för tillväxten i Asien. Utsikterna för hög tillväxt i Asien bedöms vara goda. I både Kina och Indien väntas BNP-tillväxten vara fortsatt hög samtidigt som Japans ekonomi förefaller vara starkare än på många år. 


\subsection{Den ekonomiska utvecklingen i Norden}

De nordiska ekonomierna befinner sig i ett starkt konjunkturläge understött av såväl inhemsk som global efterfrågan. Konjunkturen stärktes under 2004 och drevs i de flesta av de nordiska länderna av en stark inhemsk efterfrågan. Hushållens disponibelinkomster steg som en följd av både en expansiv penning- och finanspolitik. Dessutom ökade hushållens förmögenhetsställning av en god börsutveckling och stigande bostadspriser. Tillväxten i hushållens konsumtion uppgick till över 3 \% både 2004 och 2005 i alla de nordiska länderna (bortsett från Sverige vars tillväxt drevs av en mycket stark exportutveckling under denna period). Hög global efterfrågan har även medfört en stark exportutveckling i de flesta nordiska länderna. I takt med att konjunkturen breddades och kapacitetsutnyttjandet steg tog även investeringarna fart. En ytterligare drivkraft bakom investeringsuppgången i flera nordiska länder är att bostadsbyggandet har utvecklas i god takt. Den höga tillväxttakten i investeringarna har bidragit till en relativt utdragen högkonjunktur i de nordiska länderna. Styrkan i konjunkturen väntas bibehållas året ut. Nästa år mattas tillväxten mot bakgrund av en svagare global efterfrågan, en mindre expansiv penningpolitik samt ett mer ansträngt resursläge. Den positiva utvecklingen i de nordiska ekonomierna har lett till en tydlig förbättring på arbetsmarknaden för de flesta nordiska länderna, dock med en viss eftersläpning jämfört med tidigare konjunkturuppgångar.

BNP-tillväxten i Danmark förväntas bli 2,7 \% i år och 2,0 \% 2007. Under innevarande år bedöms den inhemska efterfrågan vara fortsatt hög. Den starka prisutvecklingen på bostadsmarknaden har stimulerat till både höga bostadsinvesteringar och hög konsumtionstillväxt. Samtidigt uppvisar den danska exporten höga tillväxttal. BNP-tillväxten väntas dämpas under 2007. Den inhemska efterfrågan förutses mattas mot bakgrund av stigande räntor och en markant uppbromsning av bostadsprisökningen. Dessutom väntas den svagare globala efterfrågan bidra till en lägre exporttillväxt.

I Finland bedöms BNP öka med hela 4,5 \% i år. En del av ökningen beror dock på strejken inom pappersindustrin i fjol som dämpade BNPtillväxten under 2005. Liksom i Danmark drivs tillväxten både av en stark inhemsk och internationell efterfrågan. Hushållens förtroende är fortsatt högt bland annat till följd av höga bostadspriser och en stigande sysselsättning. År 2007 förväntas utrymmet för en fortsatt stark konsumtionstillväxt vara begränsat till följd av hushållens relativt höga skuldkvot och låga sparande. Även exporttillväxten väntas försvagas under nästa år. BNP-tillväxten beräknas då bli 3,0 \%.

Islands BNP förväntas växa med 4,2 \% 2006 och med 1,0 \% 2007. Tillväxten är starkt kopplad till två stora investeringsprojekt för utbyggande av smältverk för aluminium samt investeringar i vattenkraftsanläggningar. De största insatserna i projekten kommer att göras under pe- 
rioden 2005-2006. BNP-tillväxten i år drivs även av en stark tillväxt i hushållens konsumtion.

BNP-tillväxten i den norska ekonomin är mycket stark främst till följd av en mycket god utveckling av hushållens konsumtion och investeringar relaterade till oljenäringen. BNP i Fastlands-Norge väntas växa med 3,4 \% i år. I takt med att penningpolitiken blir mindre expansiv mattas konsumtionstillväxten något nästa år samtidigt som investeringsuppgången dämpas markant. Nästa år beräknas BNP-tillväxten i Fastlands-Norge till 2,9\%.

I Sverige förväntas BNP-tillväxten bli 4,0 \% i år och 3,3 \% 2007. Bakgrunden till den positiva utvecklingen i år är att efterfrågan i svensk ekonomi har växt på bred front. Exporten har efter en förhållandevis svag tillväxt det första halvåret 2005 återhämtat sig avsevärt, den starka investeringskonjunkturen har fortsatt att hålla i sig och hushållens konsumtion har växt i god takt. Den något svagare BNP-tillväxten 2007 beror främst på en inbromsning i investeringarna.

\subsection{Arbetsmarknaden}

Den höga aktiviteten i de nordiska ekonomierna under de senaste åren har med viss fördröjning slagit igenom på arbetsmarknaden. Sysselsättningen har ökat och i de flesta nordiska länderna har arbetslösheten fallit markant. Resursläget på arbetsmarknaderna har blivit mer ansträngt i takt med att arbetslösheten närmar sig den långsiktigt hållbara nivån. I vissa branscher råder brist på arbetskraft.

Arbetslösheten i Danmark är historiskt låg. Den fortsatt höga efterfrågan väntas medföra ytterligare press på arbetsmarknaden och ökar risken för accelererande löneökningar. I år väntas arbetslösheten uppgå till 4,4 \% för att 2007 sjunka ytterligare till 4,1 \%.

Även i Finland har läget på arbetsmarknaden ljusnat. Arbetslösheten sjunker betydligt i år jämfört med 2005 och väntas uppgå till 7,7 \%. Nästa år väntas sysselsättningstillväxten avta. Ett minskat utbud på arbetskraft bidrar dock till att arbetslösheten faller ytterligare till 7,4 \%. Den relativt höga arbetslösheten i Finland är till stor del strukturell.

På Island har den höga ekonomiska tillväxten bidragit till en ökad efterfrågan på arbetskraft och en kraftigt sjunkande arbetslöshet. Arbetslösheten beräknas bli 1,3 \% i år. Nästa år väntas den höga efterfrågan på arbetskraft mattas och arbetslösheten väntas uppgå till 2,1 \%.

Den höga aktiviteten i den norska ekonomin har lett till en ökning av antalet sysselsatta och ett tydligt fall i arbetslösheten. I ljuset av ny information från Statistiska centralbyrån om den faktiska utvecklingen av arbetslösheten hittills i år beräknas arbetslösheten till ca 3,5 \% i år och omkring 3,3 \% nästa år. 
Den svenska sysselsättningstillväxten har varit god under 2006. Den öppna arbetslösheten har dock inte fallit i motsvarande grad som sysselsättningen stigit eftersom även arbetskraftsutbudet ökat snabbt. Samtidigt har den totala arbetslösheten ${ }^{1}$ varit i stort sett oförändrad. Den öppna arbetslösheten stiger något under loppet av år 2007, från 5,6 \% i år till 5,8\%, när antalet konjunkturberoende arbetsmarknadspolitiska program minskas kraftigt. Den totala arbetslösheten sjunker dock markant 2007.

\subsection{Penningpolitiken och pris- och kostnadsutvecklingen}

Penningpolitiken i Norden styrs av ländernas egna centralbanker, utom i Finland där den styrs av Europeiska centralbanken (ECB). Det övergripande penningpolitiska målet i de nordiska länderna är prisstabilitet.

Finlands medlemskap i EMU innebär att penningpolitiken styrs av ECB. Den primära målsättningen för ECB är att fastställa en styrränta som bibehåller prisstabilitet. Prisstabilitetsmålet är att hålla inflationen på nivåer strax under $2 \%$. Danmarks penningpolitik är inriktad på att kronan ska följa euron inom ett fluktuationsband på $+/-2,25$ procentenheter. I praktiken är fluktuationsbandet mindre. Islands penningpolitik kännetecknas sedan 2001 av en självständig centralbank vars mål är prisstabilitet. Den isländska centralbankens målsättning är att inflationen ska vara omkring 2,5\% med ett toleransintervall på $+/-1,5$ procentenheter. Det operativa målet för den norska penningpolitiken är att hålla inflationen omkring 2,5\% med ett toleransintervall på +/-1 procentenhet. Den svenska penningpolitiken styrs av Riksbanken som också har ett prisstabilitetsmål. Riksbankens mål är att hålla inflationen omkring 2 \% med ett toleransintervall på $+/-1$ procentenhet.

Stigande energipriser har bidragit till en tilltagande inflation under det senaste året. Det underliggande inflationstrycket i de nordiska ekonomierna har dock varit relativt lågt. Måttliga löneökningar och en hög produktivitetstillväxt har bland annat bidragit till ett lågt kostnadstryck. I takt med ett fortsatt ökat resursutnyttjande och en stramare arbetsmarknad förväntas löneökningstakten öka och bidra till att den underliggande inflationen tilltar. Samtidigt väntas energiprisernas bidrag till inflationen minska i samband med det förväntade lägre oljepriset under 2007.

I Finland har inflationen tilltagit under andra halvan av innevarande år främst till följd av stigande bränslepriser och räntor på bostadslån. Inflationen är dock fortsatt låg i Finland och beräknas till 1,5 \% i år och till 1,3 \% nästa år. År 2005 försvagades eurons värde i förhållande till dollarn. I början av detta år stärktes euron på nytt. Framöver väntas euron stärkas ytterligare något mot dollarn i takt med att ränteskillnaden gentemot USA minskar.

\footnotetext{
${ }^{1}$ Öppet arbetslösa och deltagare i arbetsmarknadspolitiska program som andel av arbetskraften.
} 
Den danska underliggande inflationen väntas vara fortsatt relativt låg $\mathrm{i}$ år för att stiga i takt med att löneökningarna tilltar under 2007. Inflationen mätt som KPI beräknas i år till 2,0 \% och till 1,8 \% nästa år. Den danska kronan väntas fortsätta att utvecklas i takt med euron.

I Island är inflationstrycket starkt kopplat till de stora investeringsprojekten och innovationer på den finansiella marknaden som har lett till ökade lånemöjligheter för hushållen. Centralbanken har sedan 2004 successivt höjt styrräntan. Trots den höga styrräntenivån på 14 \% beräknas inflationen till 7,3 \% i år och 4,5 \% 2007. I takt med styrräntehöjningarna har den isländska kronan stärkts. Under fjolåret stärktes den isländska kronan med hela 10,3 \%. Under innevarande år har dock växelkursen fluktuerat bland annat till följd av ofördelaktiga rapporter från utländska analytiker. Den isländska kronan förväntas emellertid stabiliseras under de närmaste åren.

Den norska inflationen har tilltagit det senaste året till följd av höga elektricitets- och bensinpriser. Nästa år förväntas lägre energiprisökningar medan en högre löneökningstakt och en relativt svag krona förutses pressa upp prisökningstakten. I år beräknas tillväxten i KPI till ca 2,5 \% och till omkring 1,8 \% nästa år. I år väntas den norska kronan appreciera, dock i en betydligt lägre takt jämfört med i fjol. Mot bakgrund av ett förväntat lägre oljepris och en minskad räntedifferens mot omvärlden väntas kronan stabiliseras framöver. 2007 väntas en svag depreciering av den norska kronan.

Energipriserna drar upp inflationen i Sverige, som mätt med KPI beräknas till 1,6 \% i år. Det underliggande inflationstrycket i svensk ekonomi förväntas dock vara fortsatt lågt under 2006. Under loppet av 2007 ökar det underliggande inflationstrycket i takt med att resursutnyttjandet stiger och löneökningstakten tilltar. Inflationsuppgången dämpas dock av sjunkande energipriser och en fortsatt kronförstärkning. Nästa år bedöms tillväxten i KPI uppgå till 2,5\%. Den svenska kronan har stärkts mot både dollarn och euron under 2006. Den främsta anledningen till den starka utvecklingen är förväntningar om en stramare penningpolitik i Sverige och en därmed en minskad ränteskillnad mot omvärlden. Denna utveckling förutses fortsätta även under nästa år.

\subsection{De offentliga finanserna}

Sunda offentliga finanser är en förutsättning för en hållbar ekonomisk tillväxt och en hög sysselsättning. För att understryka vikten av detta har länderna i Norden satt upp likartade budgetpolitiska mål för de offentliga finanserna. I Danmark är det tidigare uppställda målintervallet för det strukturella offentliga överskottet $0,5-1,5 \%$ av BNP i genomsnitt fram till 2010. Finland har som mål att upprätthålla solida offentliga finanser och att statens finanser ska vara i balans 2007. På Island är det budgetpo- 
litiska målet att inte öka den offentliga konsumtionen i reala termer med mer än 2 \% per år och begränsa transfereringstillväxten till 2,5 \% per år. Sverige har sedan 2000 ett överskottsmål för de offentliga finanserna på $2 \%$ av BNP sett över en konjunkturcykel.

Norges intäkter från oljeutvinningen gör att landet har ett betydligt högre överskott i de offentliga finanserna än de övriga länderna i Norden. Oljans speciella roll i den norska ekonomin gör att det budgetpolitiska målet är annorlunda utformat. Budgetpolitiken ska följa den så kallade handlingsregeln som säger att det oljekorrigerade strukturella budgetunderskottet skall över tiden vara lika med och finansieras med den förväntade reala avkastningen på petroleumfonden. Överskottet i de offentliga finanserna i Norge beräknas till 19,5 \% av BNP i år och till 18,6 \% 2007.

Till skillnad från många länder i Europa har länderna i Norden uppvisat överskott i sina offentliga finanser de senaste åren, och denna utveckling beräknas hålla i sig även under nästa år. I Danmark medför det goda konjunkturläget och höga oljepriser ett fortsatt högt överskott i de offentliga finanserna. Det offentliga överskottet bedöms uppgå till 3,1\% av BNP i år och 2,8 \% 2007. I Finland förväntas det offentliga överskottet förstärkas i år jämfört med i fjol och uppgå till 2,9 \% av BNP. Även 2007 består det höga överskottet och bedöms uppgå till 2,7 \% av BNP. I Island beräknas överskottet på 5,5 \% 2005 minska i år och uppgå till 3,8 \% av BNP. 2007 beräknas överskottet minska ytterligare till 1,5\% av BNP. I Sverige förväntas överskottet i den offentliga sektorn uppgå till 2,8 \% av BNP i år och till 2,3 \% av BNP 2007.

\subsection{Bytesbalansen}

Bytesbalansen har visat överskott i de flesta nordiska länder de senaste åren, och denna utveckling beräknas hålla i sig även framöver. Det enda undantaget är Island, där de stora investeringsprojekten bidrar till underskott i bytesbalansen. Underskottet i den isländska bytesbalansen beräknas bli 18,7 \% av BNP i år och 10,7 \% av BNP nästa år. På längre sikt leder investeringsprojekten till att bytesbalansen förbättras.

Danmarks bytesbalansöverskott väntas minska i år jämfört med i fjol. Bytesbalansen som procent av BNP väntas i år uppgå till 1,6 \% och till 1,7 \% nästa år. Det finska bytesbalansöverskottet förbättras i år jämfört med i 2005 och förväntas uppgå till 5,4 \% av BNP. Nästa år bidrar främst en dämpad exportutveckling till en svagare bytesbalans i Finland och bytesbalansen som procent av BNP beräknas till 4,7\%. Norges bytesbalansöverskott, som i stor utsträckning påverkas av oljepriset, beräknas bli 17,8 \% av BNP i år. Nästa år leder ett lägre oljepris till en svag försämring av bytesbalansöverskottet. 2007 beräknas överskottet i bytesbalansen till 16,9 \% av BNP. I Sverige leder både en starkare handels- och tjänste- 
balans till att bytesbalansöverskottet ökar i år jämfört med i fjol. Bytesbalansen som andel av BNP förväntas uppgå till 6,8 \% av BNP i år. Nästa år beräknas överskotten öka ytterligare och uppgå till 7,7 \% av BNP.
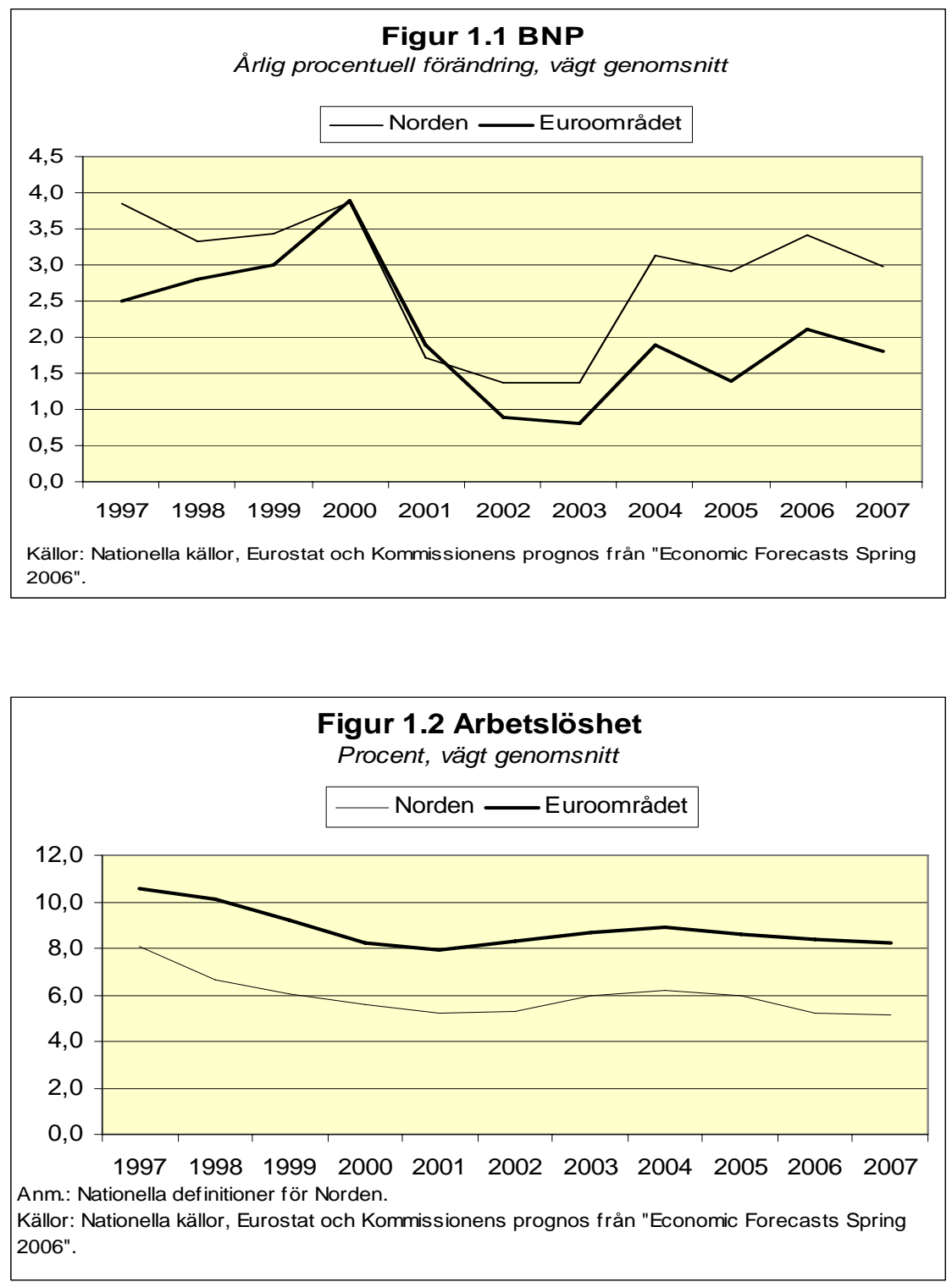


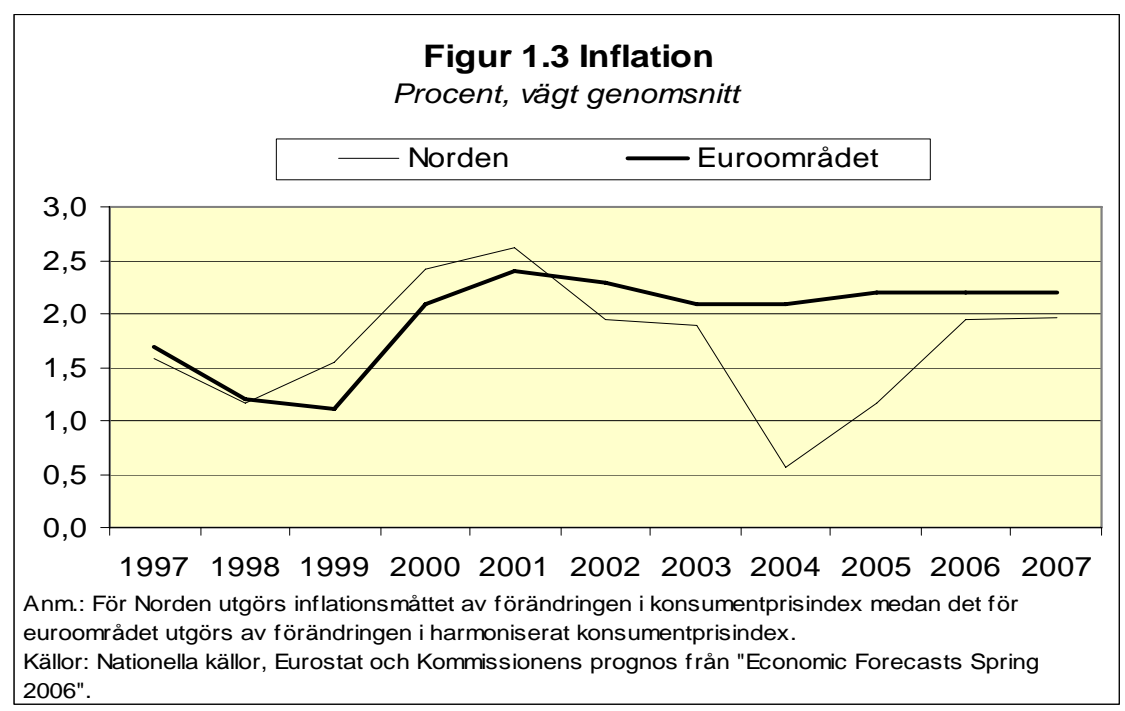

Figur 1.4 Offentliga sektorns finansiella sparande Procent av BNP, vägt genomsnitt

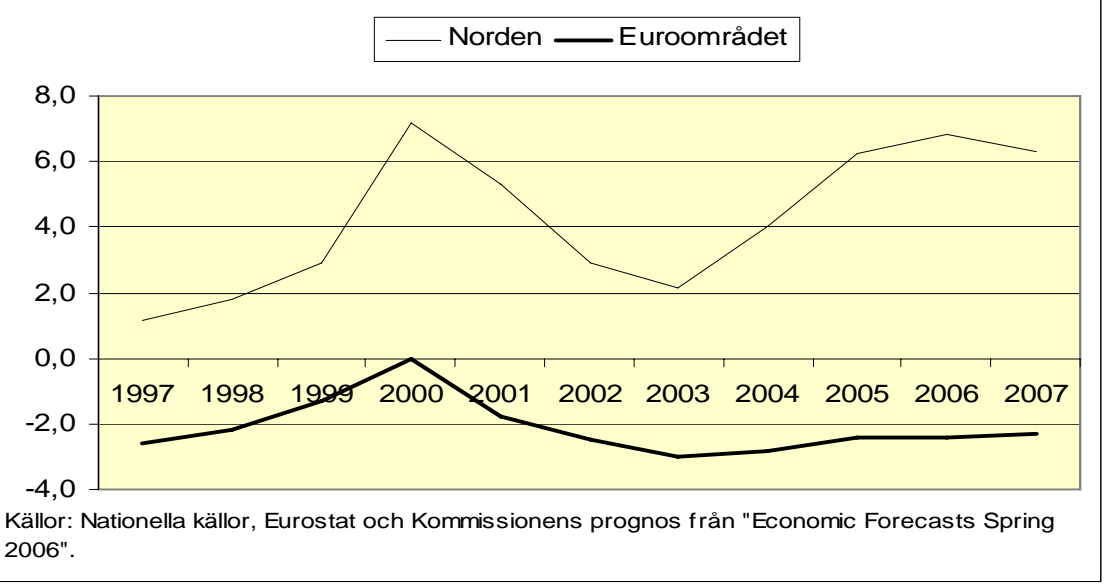


Tabell 1.1 Nyckeltal, Norden

\begin{tabular}{|c|c|c|c|c|c|}
\hline & 2003 & 2004 & 2005 & 2006 & 2007 \\
\hline \multicolumn{6}{|l|}{ BNP-tillväxt, \% } \\
\hline Danmark & 0,7 & 1,7 & 3,6 & 2,7 & 2,0 \\
\hline Finland & 1,8 & 3,5 & 2,9 & 4,5 & 3,0 \\
\hline Island & 2,7 & 7,7 & 7,5 & 4,2 & 1,0 \\
\hline Norge & 1,1 & 3,1 & 2,3 & 2,4 & 3,6 \\
\hline Sverige & 1,7 & 3,7 & 2,7 & 4,0 & 3,3 \\
\hline Norden, vägt genomsnitt & 1,4 & 3,1 & 2,9 & 3,4 & 3,0 \\
\hline \multicolumn{6}{|l|}{ Inflation, \% (KPI) } \\
\hline Danmark & 2,1 & 1,2 & 1,8 & 2,0 & 1,8 \\
\hline Finland & 0,9 & 0,2 & 0,9 & 1,5 & 1,3 \\
\hline Island & 2,1 & 3,2 & 4,0 & 7,3 & 4,5 \\
\hline Norge & 2,5 & 0,4 & 1,6 & 2,5 & 1,8 \\
\hline Sverige & 1,9 & 0,4 & 0,5 & 1,6 & 2,5 \\
\hline Norden, vägt genomsnitt & 1,9 & 0,6 & 1,2 & 1,9 & 2,0 \\
\hline \multicolumn{6}{|l|}{ Arbetslöshet, \% } \\
\hline Danmark & 5,9 & 6,1 & 5,4 & 4,4 & 4,1 \\
\hline Finland & 9,0 & 8,8 & 8,4 & 7,7 & 7,4 \\
\hline Island & 3,4 & 3,1 & 2,1 & 1,3 & 2,1 \\
\hline Norge & 4,5 & 4,5 & 4,6 & 3,5 & 3,3 \\
\hline Sverige & 5,3 & 6,0 & 6,0 & 5,6 & 5,8 \\
\hline Norden, vägt genomsnitt & 6,0 & 6,2 & 6,0 & 5,2 & 5,1 \\
\hline \multicolumn{6}{|c|}{ Offentligt finansiellt sparande, $\%$ av BNP } \\
\hline Danmark & $-0,1$ & 1,7 & 4,0 & 3,1 & 2,8 \\
\hline Finland & 2,3 & 2,1 & 2,5 & 2,9 & 2,7 \\
\hline Island & $-2,0$ & 0,5 & 5,5 & 3,8 & 1,5 \\
\hline Norge & 7,5 & 11,4 & 16,4 & 19,5 & 18,6 \\
\hline Sverige & $-0,2$ & 1,6 & 2,8 & 2,8 & 2,3 \\
\hline Norden, vägt genomsnitt & 2,1 & 4,0 & 6,2 & 6,8 & 6,3 \\
\hline \multicolumn{6}{|l|}{ Bytesbalans, $\%$ av BNP } \\
\hline Danmark & 3,2 & 2,3 & 3,0 & 1,6 & 1,7 \\
\hline Finland & 5,9 & 7,6 & 4,6 & 5,4 & 4,7 \\
\hline Island & $-4,8$ & $-9,9$ & $-16,1$ & $-18,7$ & $-10,7$ \\
\hline Norge & 13,0 & 13,6 & 16,6 & 17,8 & 16,9 \\
\hline Sverige & 7,3 & 6,8 & 6,4 & 6,8 & 7,7 \\
\hline Norden, vägt genomsnitt & 7,3 & 7,3 & 7,4 & 7,6 & 7,7 \\
\hline
\end{tabular}

Källor: Nationella källor. 


\section{Danmark}

\subsection{Den økonomiske politik}

Det er et mål for den økonomiske politik at sikre holdbar økonomisk vækst, høj beskæftigelse og lav og stabil inflation. Med henblik på at opnå disse mål er der i tilrettelæggelsen af den økonomiske politik et særligt fokus på at ruste dansk økonomi til at håndtere udfordringerne fra den demografiske udvikling og samtidig udnytte mulighederne fra globaliseringen.

I juni 2006 indgik et bredt flertal i Folketinget en aftale om fremtidens velstand og velfcerd og investeringer i fremtiden. Samtidig indgik man en aftale om fremtidig indvandring. Velfærdsaftalerne indeholder reformer og initiativer, der under ét bidrager til at sikre balancen i velfærdssamfundets økonomi i lang tid frem. Desuden omfatter aftalerne en række tiltag, som på kortere sigt bidrager til at styrke arbejdsudbuddet.

De indgåede aftaler indebærer ændringer i tilbagetrækningssystemet, idet efterlønsalderen gradvist hæves i 2019-2022 fra 60 til 62 år, mens folkepensionsalderen hæves i 2024-2027 fra 65 til 67 år. Fra 2025 indekseres aldersgrænserne i pensionssystemet med levetiden for 60-årige, således at perioden med efterløn og folkepension er omkring 191/2 år på længere sigt. Der gennemføres initiativer til at styrke beskæftigelsen for de ældre og forebygge nedslidning. Endvidere er der aftalt justeringer af aktiveringsreglerne og en styrkelse af jobformidlingen, og samtidig gennemføres særlige initiativer med henblik på at få flere indvandrere og efterkommere i arbejde. Endelig er der vedtaget reformer med henblik på at styrke voksen- og efteruddannelserne og få unge hurtigere i gang med, og hurtigere gennem, de videregående uddannelser.

De nævnte tiltag i velfærdsaftalerne indebærer på langt sigt en styrkelse af de offentlige finanser, der primært reserveres til at sikre finansieringen af velfærdssamfundet i fremtiden. Ud fra en holdbarhedsbetragtning forøger tiltagene samtidig de kortsigtede finanspolitiske handlemuligheder. Fra 2007 opbygges en globaliseringspulje til investeringer i fremtiden, herunder navnlig i forskning og uddannelse. Puljen vokser gradvist til 10 mia. kr. i 2012 og udmøntes af partierne bag velfærdsaftalerne. Det er blandt andet målet, at mindst $95 \%$ af alle unge skal gennemføre en ungdomsuddannelse i 2015, og at mindst $50 \%$ af alle unge skal have en videregående uddannelse i 2015.

Aftalen om fremtidig indvandring omfatter blandt andet tiltag, der giver højtkvalificerede udlændinge bedre mulighed for at arbejde i Danmark via en udvidelse af jobkort-ordningen og indførelse af en såkaldt Green-card ordning. 
Udgangspunktet for den mellemfristede finanspolitik er fortsat at sikre langsigtet finanspolitisk holdbarhed. Det vil sige, at den besluttede finanspolitik under en række opstillede langsigtede forudsætninger om rente, levetid m.v. i princippet og overordnet vil kunne videreføres i de efterfølgende år. Velfærdsaftalerne medfører, at 2010-planens holdbarhedsmålsætninger indfries på sigt.

Finanspolitikken anslås i indeværende år at have en svag positiv aktivitetsvirkning. Den reale vækst i udgifterne til offentlige service mv. anslås til 1,1 \% i 2006. Det er lidt mere end oprindeligt planlagt, hvilket blandt andet afspejler en forøget amtskommunal indsats på sundhedsområdet.

Den vedtagne reform af den offentlige sektor træder i kraft pr. 1. januar 2007. Reformen vedrører blandt andet opgavefordelingen mellem de offentlige myndigheder og en omlægning af kommune- og amtsstrukturerne. De nuværende 271 kommuner sammenlægges således til 98 nye kommuner, mens de nuværende 13 amter nedlægges til fordel for fem regioner, som primært skal drive hospitalerne.

Velfærdsaftalerne indebærer som udgangspunkt, at rammen for den reale vækst i de offentlige udgifter til service mv. forøges fra $1 / 2 \%$ om året til 1 \% i årene 2007-2010. Rammeløftet afspejler navnlig den nævnte styrkelse af uddannelserne og forskning, som på længere sigt kan øge vækstpotentialet. For 2007 er der forudsat et fald i de offentlige investeringer, efter et ret højt niveau i 2006 i forbindelse med kommunesammenlægningen. Samlet skønnes finanspolitikken for 2007 således at have en nogenlunde neutral aktivitetsvirkning.

I lyset af den aktuelle konjunktursituation med høj kapacitetsudnyttelse og pres på arbejdsmarkedet er det centralt, at de indgåede aftaler om økonomien i kommuner og regioner bliver overholdt.

Ovenpå det rekordstore overskud på de offentlige finanser i 2005 på 3,9 \% af BNP ventes der lidt mindre overskud i 2006 og 2007 på henholdsvis 3,1 og 2,8 \% af BNP. Det igangværende konjunkturopsving samt store indtægter fra olie- og gasaktiviteterne i Nordsøen bidrager til de store overskud. Den markante forbedring af den offentlige saldo siden 2003 afspejler således i betydeligt omfang en midlertidig styrkelse af de offentlige finanser. De aktuelt store offentlige overskud går til nedbringelse af gælden. Det er vigtigt af hensyn til konjunktursituationen og kravet om langsigtet finanspolitisk holdbarhed, som blandt andet knytter sig til at sikre finansiering af pleje og sundhedsydelser til et stigende antal ældre.

Skattepolitikken er centreret omkring det såkaldte skattestop, som blev indført fra 2002. Skattestoppet indebærer, at ingen skat eller afgift må stige, uanset om den er fastsat i procentstørrelse eller i nominelle kronebeløb.

Pengepolitikken er fortsat indrettet efter, at kronen skal følge euroen inden for et snævert udsvingsbånd på +/- 2,25 \% Renteudviklingen i 
Danmark er dermed i praksis bestemt af renteudviklingen i euroområdet. Den Europæiske Centralbank har hævet styringsrenten flere gange siden årsskiftet. Med de allerede gennemførte og forventede yderligere rentestigninger vil den samlede pengepolitik i Danmark gå fra at være meget lempelig til at være mere neutral. Det vil bidrage til at dæmpe væksten i efterspørgslen og reducere risikoen for et ubalanceret forløb.

Regeringen har nedsat et ministerudvalg, der skal lede arbejdet med en kvalitetsreform rettet mod at forbedre kvaliteten af den offentlige service inden for de givne rammer. Strategien skal ligge færdig inden sommeren 2007.

Regeringen vil i efteråret 2007 fremlægge en ny økonomisk flerårsplan for Danmark. Planen vil række mindst til 2015 og vil indeholde mål for udviklingen i dansk økonomi på mellemfristet sigt.

\subsection{Udviklingen i dansk økonomi}

Det økonomiske opsving i Danmark har nu været i gang i næsten tre år og med historisk lav ledighed, høj beskæftigelse samt overskud på de offentlige finanser og betalingsbalancen fremstår nøgletallene for dansk økonomi ekstraordinært gode.

I Økonomisk Redegørelse, august 2006, har Finansministeriet fremlagt sin seneste prognose for udviklingen i dansk økonomi. Prognosen er baseret på, at væksten i produktion og efterspørgsel reduceres frem mod udgangen af 2007. Det ventes således, at BNP-væksten tager af fra 3,6 \% i 2005 til 2,7 og 2,0 \% i henholdsvis 2006 og $2007 .^{2}$

Der forudses en fortsat kraftig fremgang i den indenlandske efterspørgsel i 2006, hvor både det private forbrug og investeringerne ventes at vokse markant. Den betydelige forbrugsopgang skal ses i lyset af de stigende disponible indkomster samt en fortsat vækst i forbrugskvoten, der er drevet af den lave rente, de stigende ejerboligpriser og gode lånemuligheder. Den kraftige vækst i de faste erhvervsinvesteringer stimuleres blandt andet af den høje kapacitetsudnyttelse. Samtidig understøttes en fortsat stærk fremgang i boliginvesteringerne af de høje ejendomspriser, der gør privat nybyggeri mere økonomisk attraktivt.

På boligmarkedet ventes der i sidste halvdel af indeværende år en ret markant opbremsning i væksten i ejendomspriserne efter, at år til år væksten i den første del af året var på ca. 25 \% Denne forventning understøttes af, at liggetiderne for udbudte boliger på det seneste er forøget betydeligt, samtidig med at der er observeret en klar afdæmpning af prisstigningerne på nogle områder.

Den aktuelt pæne fremgang i eksporten drives blandt andet af den tiltagende vækst på eksportmarkederne. Industrieksporten vokser således kraftigt, hvilket indebærer, at der ligesom i 2005 vindes markedsandele i

\footnotetext{
${ }^{2}$ Opgjort i 2000-priser.
} 
indeværende år. Det er ret usædvanligt i en situation med voksende og positivt output gab. Udviklingen vurderes blandt andet at kunne tilskrives en vis fremgang i reeksporten af varer, der kun i mindre lægger beslag på dansk produktionskapacitet. Dertil kommer, at år til år-væksten i industrieksporten i 2006 er påvirket af et højt niveau ved udgangen af 2005. Den betydelige efterspørgsel og den høje kapacitetsudnyttelse medfører en kraftig vækst i importen, hvilket dæmper BNP-væksten i forhold til stigningen i efterspørgslen. ${ }^{3}$

Den økonomiske vækst ventes at aftage i styrke i 2007, hvor en højere rente og en yderligere afdæmpning af prisstigningerne på boliger forudses at medvirke til at dæmpe den private forbrugsvækst og væksten i investeringerne. Eksportfremgangen forventes desuden at aftage i 2007, idet væksten på eksportmarkederne bliver langsommere, og konkurrenceevnen svækkes som følge af tiltagende lønstigninger. Væksten i importen ventes at aftage, i takt med at efterspørgselsudviklingen bliver mere dæmpet.

Opsvinget har ført til en markant fremgang i beskæftigelsen, der ventes at aftage i styrke frem mod 2007, hvor beskæftigelsesudviklingen efterhånden vil flade ud. Da arbejdsstyrken er næsten uændret slår stigningerne i beskæftigelsen ud i stort set tilsvarende fald i ledigheden. Den registrerede ledighed vurderes således at falde til 120.000 personer i 2007 svarende til 4,1 \% af arbejdsstyrken. Den aktuelt lave ledighed giver anledning til pres på arbejdsmarkedet og mangel på arbejdskraft inden for især byggeriet. Situationen indebærer samtidig en god mulighed for beskæftigelse af personer med lav tilknytning til arbejdsmarkedet.

Lønstigningerne er fortsat relativt moderate i forhold til konjunktursituationen, hvilket til en vis grad kan afspejle tilgang af arbejdskraft fra de nye EU-lande. Det øgede pres på arbejdsmarkedet ventes at føre til en gradvis forøgelse af lønstigningstakten for den private sektor, der i 2007 forudses at udgøre 4,2 \% Udviklingen i lønningerne ventes at medvirke til en højere underliggende inflation, men aftagende og efterhånden negativ vækst i energipriserne bidrager til at dæmpe stigningerne i forbrugerpriserne, der vurderes at blive på 2,0 og 1,8 \% i henholdsvis 2006 og 2007.

Den kraftige fremgang i efterspørgslen og den heraf afledte opgang i importen har givet anledning til en svækkelse af betalingsbalanceoverskuddet. Saldoen på betalingsbalancen ventes således at aftage fra $3 \%$ af BNP i 2005 til 1,6 og 1,7 \% af BNP i henholdsvis 2006 og 2007. Fortsat store nettoindtægter fra handel med søtransport er med til at holde overskuddet oppe. Dertil kommer, at nettooverførslerne af formueindkomst fra udlandet tiltager i takt med, at Danmarks finansielle status over for

\footnotetext{
${ }^{3}$ De seneste nationalregnskabstal indikerer, at forrige års virksomhedsovertagelse inden for rederierhvervet har givet anledning til et løft i tjenestehandlen. Der indebærer, at de seneste skøn for væksten i eksporten og importen kan være undervurderet.
} 
udlandet forbedres. I løbet af 2005 blev udlandsgælden elimineret, og Danmarks nettoaktiver over for udlandet er nu positive.

Den høje kapacitetsudnyttelse og stigende pres på arbejdsmarkedet udgør en risikofaktor for dansk økonomi. Prognosens balancerede forløb med en gradvist aftagende økonomisk vækst forudsætter, at efterspørgslen dæmpes, og at import kan træde i stedet for dansk produktion, således at presset på de danske produktionsresurser aftager. Fortsat kraftig fremgang i efterspørgslen samt manglende tilbageholdenhed ved de kommende overenskomstforhandlinger i foråret 2007 vil kunne medføre større løn- og prisstigninger, der vil forværre konkurrenceevnen og dermed øge risikoen for et ustabilt forløb.

Tabell 2.1 Nyckeltal för Danmarks ekonomi. Procentuell förändring. ${ }^{1)}$

\begin{tabular}{|c|c|c|c|c|}
\hline & $\begin{array}{r}\text { Mdr. kronor } \\
2005\end{array}$ & 2005 & 2006 & 2006 \\
\hline \multicolumn{5}{|l|}{ Fasta priser } \\
\hline Hushållens konsumtionsutgifter & 753 & 3,8 & 3,1 & 2,0 \\
\hline Offentliga konsumtionsutgifter & 402 & 1,2 & 1,1 & 1,0 \\
\hline Fasta bruttoinvesteringar & 324 & 9,3 & 10,6 & 4,0 \\
\hline Näringsliv & 209 & 8,9 & 11,2 & 5,0 \\
\hline Bostäder & 87 & 12,4 & 10,0 & 6,0 \\
\hline Myndigheter & 28 & $-1,7$ & 8,1 & $-10,0$ \\
\hline Lagerinvesteringar ${ }^{2)}$ & 0 & 0,0 & 0,1 & 0,0 \\
\hline Total inhemsk efterfrågan & 1479 & 4,3 & 4,4 & 2,2 \\
\hline Export & 750 & 8,7 & 6,5 & 3,4 \\
\hline Import & 675 & 10,6 & 10,3 & 3,8 \\
\hline Bruttonationalprodukt & 1555 & 3,6 & 2,7 & 2,0 \\
\hline Sysselsättning, 1000 personer & - & 2739 & 2772 & 2780 \\
\hline Arbetslöshet (\% av arbetskraften, DK-def.) & - & 5,4 & 4,4 & 4,1 \\
\hline Konsumtionsprisindex & - & 1,8 & 2,0 & 1,8 \\
\hline Lön ${ }^{3)}$ & - & 3,6 & 3,6 & 4,2 \\
\hline Effektiv valutakurs ${ }^{4)}$ & - & $-0,6$ & 0,1 & 0,4 \\
\hline Bytesförhållande & - & 0,8 & 0,0 & 0,0 \\
\hline Bytesbalans (\% av BNP) & - & 3,0 & 1,6 & 1,7 \\
\hline 3-månaders penningmarknadsränta (nivå) & - & 2,2 & 3,1 & 3,6 \\
\hline $\begin{array}{l}\text { 1) Beräknat i fasta priser, basår } 2000 . \\
\text { 2) Förändring i procent av föregående års BNP. } \\
\text { 3) Timlön för anställda, DA-løn. } \\
\text { 4) Negativt tal innebär depreciering. }\end{array}$ & & & & \\
\hline
\end{tabular}

\subsection{Udsigterne på mellemlangt sigt}

Vækstmulighederne i dansk økonomi i årene efter 2007 begrænses af den aktuelt meget lave ledighed. Dertil kommer, at det demografiske bidrag til væksten i arbejdsstyrken vil være negativt. Selv fra et udgangspunkt 
med normal kapacitetsudnyttelse ville vækstmulighederne fra 2008 og frem mod 2010 som følge af den demografiske udvikling måske ikke være meget mere end $1 \frac{1}{2} \%$ om året i gennemsnit ved en normal produktivitetsudvikling.

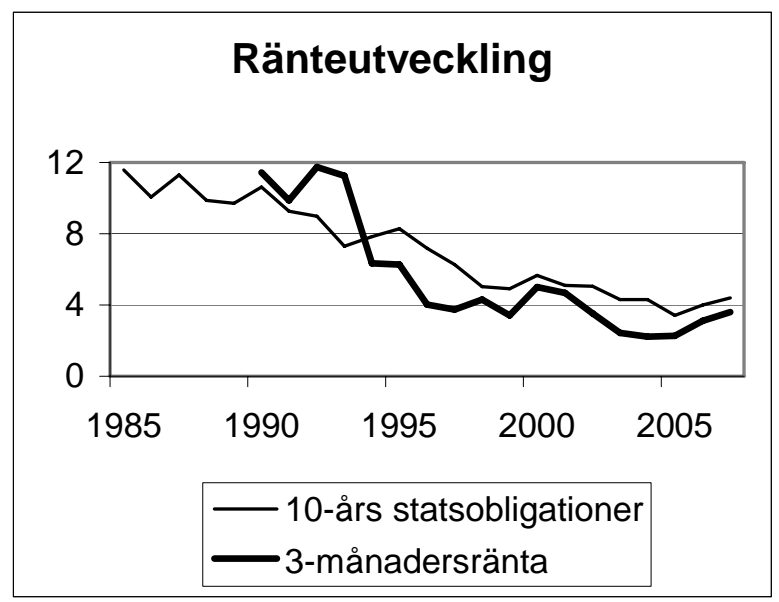

Figur 2.1 Korta och långa nominella räntor. Procent. Källa: Finansministeriet.

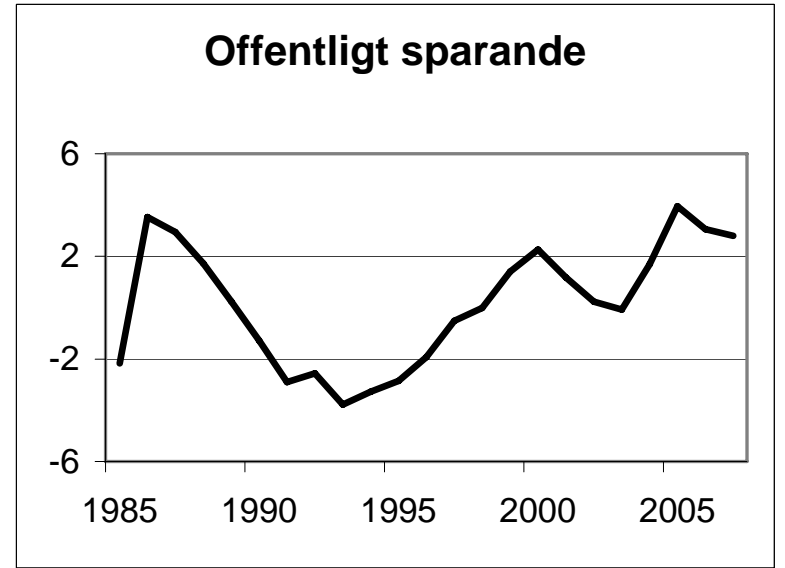

Figur 2.2 Det offentliga finansiella sparandet. Procent av BNP. Källa: Finansministeriet. 


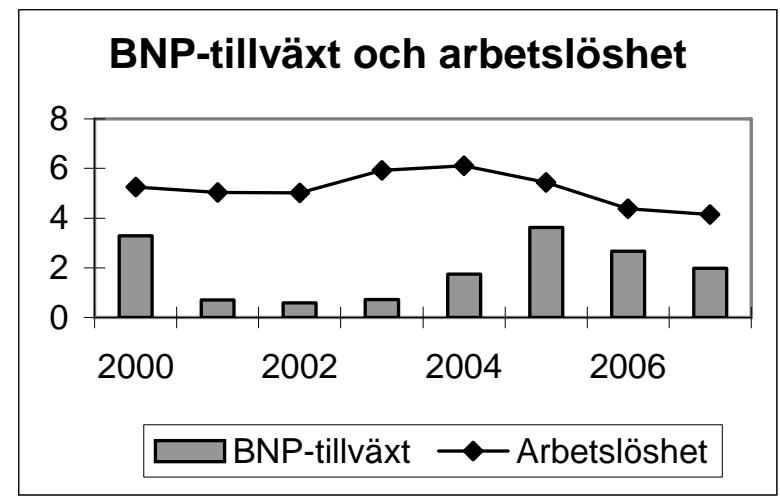

Figur 2.3 BNP-tillväxt och arbetslöshet. Procentuell förändring från föregående år och procent av arbetskraften.

Källa: Finansministeriet.

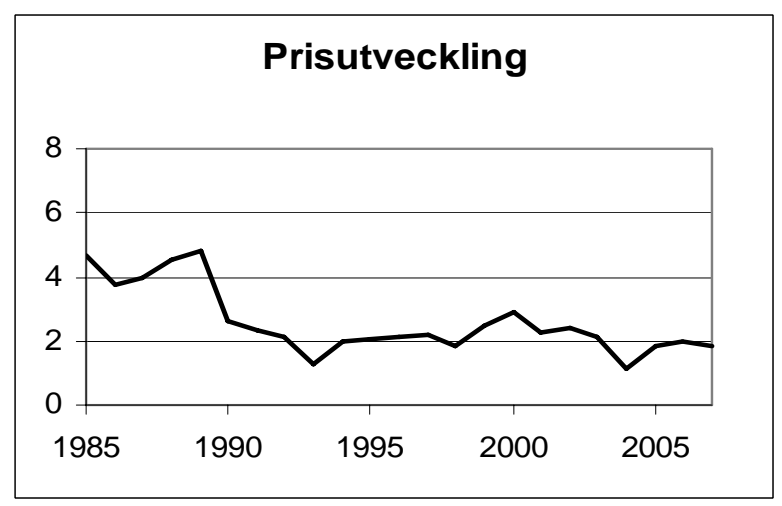

Figur 2.4 Konsumentprisindex.

Källa: Finansministeriet.

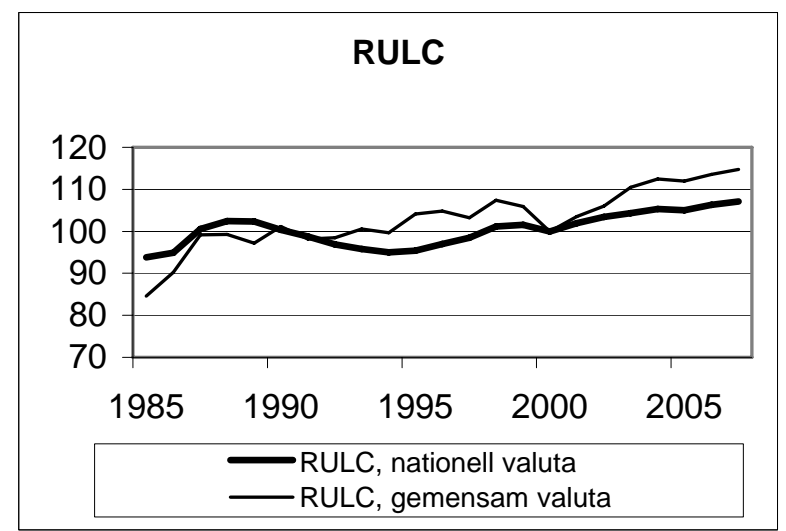

Figur 2.5 Relativ lönekostnad per producerad enhet. Basår 2000. Källa: Finansministeriet. 


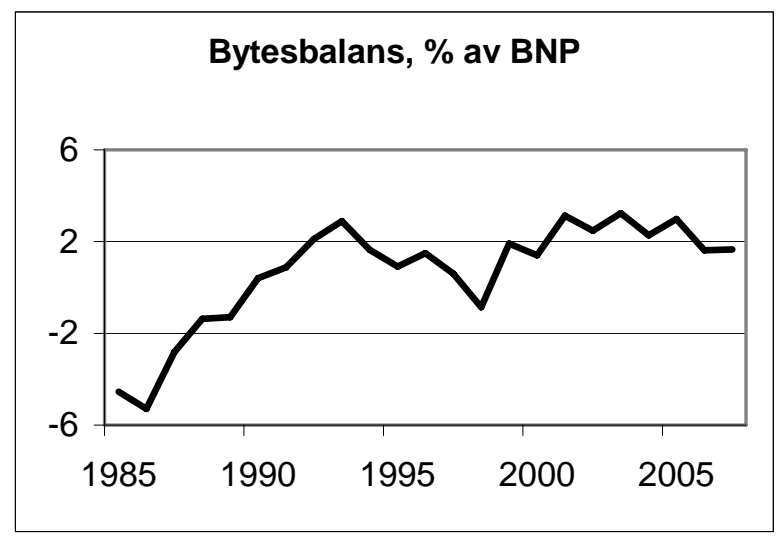

Figur 2.6 Bytesbalans. Procent av BNP.

Källa: Finansministeriet. 


\section{Finland}

\subsection{Den ekonomiska politiken}

Det viktigaste målet för regeringens ekonomiska politik är ökad sysselsättning bland annat för att kunna stå emot det utgiftstryck på den offentliga ekonomin som beror på befolkningens stigande medelålder. Regeringens budgetar har stött den ekonomiska tillväxten och sysselsättningen genom skatteåtgärder, anslagsökningar som förbättrar förutsättningarna för ekonomisk tillväxt och strukturella reformer. Sysselsättningen fortsätter att öka i år och nästa år, om än långsammare än i fjol, så målet att under regeringsperioden skapa 100000 arbetsplatser uppnås inte riktigt.

Den offentliga ekonomins finansiella situation förstärks och år 2006 uppstår ett överskott i statsfinanserna, som består under hela regeringsperioden. I och med den gynnsamma ekonomiska utvecklingen har skatteinkomsterna ökat snabbare än vad man i regeringsperiodens början beräknade. Dessutom har den strama utgiftslinjen bibehållits och den årliga tillväxten i förvaltningsområdenas reella utgifter stannar på i genomsnitt $1,2 \%$ under den här regeringsperioden.

I fjol lindrades inte löntagarnas medelbeskattning, eftersom den genomsnittliga kommunalskatteprocenten och löntagarnas arbetslöshetsförsäkringspremie samt arbetspensionspremien för personer över 53 år steg. Men både 2006 och 2007 kommer lindringen av statens inkomstbeskattning på nytt att stödja köpkraften. Möjligheterna till sysselsättning stöds också av nya åtgärder, t.ex. det år 2006 tillfälligt införda låglönestödet till arbetsgivare som på heltid anställer 54 år fyllda arbetstagare till en lön av 900-2 000 euro per månad, samt åtgärderna i budgeten för år 2007 för att få arbetsmarknaden att fungera bättre. Finanspolitiken blir både i år och nästa år närmast neutral, trots de omfattande lindringarna av löneinkomstbeskattningen. De av de offentliga samfunden insamlade skatterna och socialskyddsavgifterna i förhållande till bruttonationalprodukten var i fjol 43,8 \% och skuldförhållandet var 40,5\%. I år sjunker skattegraden med en knapp procentenhet och skuldsättningsgraden ännu mer, till 38,4 \%. De offentliga utgifterna i relation till BNP har hållit sig kring drygt $50 \%$, men beräknas i år sjunka till $49 \%$.

\subsection{Den ekonomiska utvecklingen}

Den ekonomiska tillväxten i Finland genomgår just nu konjunkturcykelns snabbaste fas. Den totala produktionen har ökat med 3 \% i några år, och i år stiger tillväxten till 4,5\%. En del av ökningen beror på att referensni- 
vån 2005 sjönk till följd av arbetsmarknadstvisten inom skogsindustrin. Den ekonomiska tillväxten är i hög grad beroende av såväl utländsk som inhemsk efterfrågan. År 2007 beräknas tillväxten åter bli långsammare och stanna på $3 \%$.

Sysselsättningen har förbättrats kraftigt under de två senaste åren. År 2006 stiger sysselsättningsgraden till 68,8 \%. Efterfrågan på arbetskraft har ökat i synnerhet inom de privata tjänsterna och byggbranschen, men också inom industrin. Utbudet på arbetskraft har likaså ökat eftersom äldre arbetstagare stannar kvar längre i arbetslivet medan de unga aktivare än förut söker sig ut på arbetsmarknaden. Arbetslöshetsgraden sjunker 2006 till 7,7 \%, och 2007 beräknas arbetslöshetsgraden sjunka till 7,4 \% i och med att utbudet på arbetskraft minskar. Den strukturella arbetslösheten förblir likväl hög, och den utgör tillsammans med matchningsproblemen på arbetsmarknaden en växande riskfaktor när det gäller en stabil ekonomisk tillväxt. Sysselsättningsökningen har under de senaste månaderna avtagit något.

Konsumentprisindexets årshöjning stannade intill 1 procent i början av året, men inflationen har tilltagit sedan dess och var nästan 2 procent $\mathrm{i}$ slutet av juni. Industrins producentpriser har höjts betydligt snabbare än konsumentpriserna, höjningen har redan överskridit 5 procent. Förtjänstnivåindexets årshöjning avtog under det andra kvartalet till 2,2 procent, men tilltar mot slutet av året mot 3 procent tack vare sommarens löneförhöjningar. Sänkningen av arbetslöshetsgraden stannade under sommaren vid 7,7 procent eftersom sysselsättningsökningen avtog.

I förhållande till hushållens konsumtions- och investeringsutgifter ökade deras disponibla realinkomst rätt lite i fjol, endast en procent. Hushållens stärkta förtroende, den snabbt växande sysselsättningen och den skäliga ökningen i löntagarnas köpkraft i kombination med den kraftigt tilltagande upplåningen upprätthöll dock en stark konsumtionsökning på nästan $4 \%$. I år fortsätter samma trend, men det faktum att skulden i förhållande till den disponibla inkomsten redan närmar sig $100 \%$ och att sparandet är negativt för tredje året i följd börjar begränsa uppgången i konsumtion och bostadsinvesteringar år 2007 och utgör en småningom växande riskfaktor för den ekonomiska tillväxten.

Byggandet har varit livligt i snart fyra års tid. En stor del av industrins fasta investeringar går till utlandet men med uppbackning av den starka efterfrågan och den goda lönsamheten byggs och förnyas också inhemsk kapacitet. De fasta investeringarnas andel av BNP stiger men ligger alltjämt just under $20 \%$. Utgifterna för forskning och utveckling har redan länge hållit internationellt hög nivå och syns inte med tillnärmelsevis hela sin tyngd i statistiken över kapitalstocken, men ökar produktionsmöjligheterna markant, särskilt inom teknologiindustrin.

Den höga kostnadsnivån har redan i flera års tid ökat andelen varor tillverkade i länder med låg kostnadsnivå i den inhemska efterfrågan och produktionen. Därför har också export och import fortsatt att växa starkt. 
Vid sidan av varuexporten har tjänsteexporten överstigit tidigare prognoser, och när det gäller tjänsteexporten kan Finland inte längre anses vara ett underutvecklat euroland. Bytesförhållandet i utrikeshandeln fortsätter att försvagas en aning, men överskottet i bytesbalansen förblir stort både i år och nästa år.

Den ökade ekonomiska tillväxten och det förbättrade sysselsättningsläget har förbättrat den offentliga ekonomins finansiella ställning. De genomförda skattelättnaderna har stött den ekonomiska tillväxten. Den ökade sysselsättningen och tillväxten i den privata konsumtionen har stärkt skattebasen. Överskottet inom hela den offentliga ekonomin håller på att stabiliseras och blir nästan $3 \%$ i relation till den totala produktionen under innevarande och nästa år. Också statens och kommunernas sammanräknade finansiella ställning uppvisar ett litet överskott.

Den offentliga sektorns finansiella överskott i relation till bruttonationalprodukten blev i fjol omkring 2,5\%, och beräknas i år och nästa år stiga till knappt $3 \%$. År 2006 uppstår i statsfinanserna ett överskott. Kommunalekonomin förbättras klart i år och nästa år på grund av att skatteinkomsterna vuxit snabbare än beräknat. Trots det går den kommunala ekonomin alltjämt en aning på minus, även om ökningen i kommunernas utgifter väntas att bli något långsammare. Överskottet i socialskyddsfonderna är nästan oförändrat och tack vare dessa överskott går hela den offentliga ekonomin på plus. Arbetspensionsfondernas växande placeringsstock utgjorde i slutet av fjolåret $66 \%$ i relation till totalproduktionen.

\subsection{Utsikterna på medellång sikt}

Trots de senaste årens snabba ekonomiska tillväxt håller tillväxtförutsättningarna på medellång sikt, fram till år 2011, på att försämras. I början av 2010-talet väntas den årliga ekonomiska tillväxten gå ner under $2 \%$. Tillväxtmöjligheterna försämras särskilt av att befolkningen åldras, vilket minskar utbudet på arbetskraft, men också av den svagt växande produktionskapaciteten under detta decennium. Omfördelningen av den internationella produktionen innebär också att den inhemska produktionen måste anpassas till de nya förhållandena.

Enligt Statistikcentralens befolkningsprognos börjar befolkningen i arbetsför ålder minska omkring decennieskiftet. Ökningen i utbudet av arbetskraft kan väntas börja minska redan tidigare, om inte den genomsnittliga pensioneringsåldern klart kan höjas från nuvarande nivå. Den pensionsreform som trädde i kraft i början av år 2005 beräknas dock bidra till att begränsa nedgången i utbudet av arbetskraft.

Produktivitetsökningen väntas gå ner till cirka 2 \% när arbetsplatserna minskar inom industrin, där produktiviteten är högre, och ökar inom ser- 
vicesektorerna, där den är lägre. Inkomstnivån beräknas på medellång sikt stiga med cirka 3 \% per år.

Överskottet i hela den offentliga ekonomin i förhållande till BNP beräknas ända till decenniets slut ligga kring $3 \%$. Statsskulden i relation till totalproduktionen minskar under samma period och närmar sig $30 \%$. Statsskulden minskar också räknat i euro, medan kommunernas skulder förblir ungefär oförändrade. Finland uppfyller kriterierna enligt EUländernas stabilitets- och tillväxtpakt när det gäller balansen i den offentliga ekonomin och skuldsättningen också på medellång sikt.

Tabell 3.1 Nyckeltal för Finlands ekonomi. Procentuell förändring. ${ }^{1)}$

\begin{tabular}{|c|c|c|c|c|}
\hline & $\begin{array}{r}\text { Mdr. euro } \\
2005\end{array}$ & 2005 & 2006 & 2007 \\
\hline \multicolumn{5}{|l|}{ Fasta priser } \\
\hline Hushållens konsumtionsutgifter & 81 & 3,8 & 3,6 & 2,7 \\
\hline Offentliga konsumtionsutgifter & 35 & 1,6 & 1,0 & 0,7 \\
\hline Fasta bruttoinvesteringar & 30 & 3,3 & 5,3 & 3,7 \\
\hline Näringsliv & 17 & 6,1 & 5,7 & 5,4 \\
\hline Bostäder & 9 & 6,3 & 6,5 & 3,5 \\
\hline Myndigheter & 4 & $-10,5$ & 3 & 1,5 \\
\hline Lagerinvesteringar ${ }^{2)}$ & - & - & - & - \\
\hline Total inhemsk efterfrågan & 148 & 4,2 & 2,8 & 2,6 \\
\hline Export & 66 & 7,3 & 10,4 & 5,2 \\
\hline Import & 57 & 12,3 & 6,9 & 4,7 \\
\hline Bruttonationalprodukt & 157 & 2,9 & 4,5 & 3,0 \\
\hline Sysselsättning, personer & - & 1,5 & 1,5 & 0,7 \\
\hline Arbetslöshet (\% av arbetskraften) & - & 8,4 & 7,7 & 7,4 \\
\hline Konsumtionsprisindex & - & 0,9 & 1,5 & 1,3 \\
\hline Lön ${ }^{3)}$ & - & 3,9 & 2,9 & 2,5 \\
\hline Effektiv valutakurs ${ }^{4)}$ & - & - & - & - \\
\hline Bytesförhållande & - & $-3,5$ & $-2,0$ & $-2,0$ \\
\hline Bytesbalans ( $\%$ av BNP). & - & 4,6 & 5,4 & 4,7 \\
\hline 3-månaders penningmarknadsränta (nivå) & - & 2,2 & 3,0 & 3,6 \\
\hline $\begin{array}{l}\text { 1) Beräknat i fasta priser, basår } 2000 . \\
\text { 2) Förändring i \% av föregående års BNP. } \\
\text { 3) Löneindex. } \\
\text { 4) Positivt tal innebär depreciering. }\end{array}$ & & & & \\
\hline
\end{tabular}




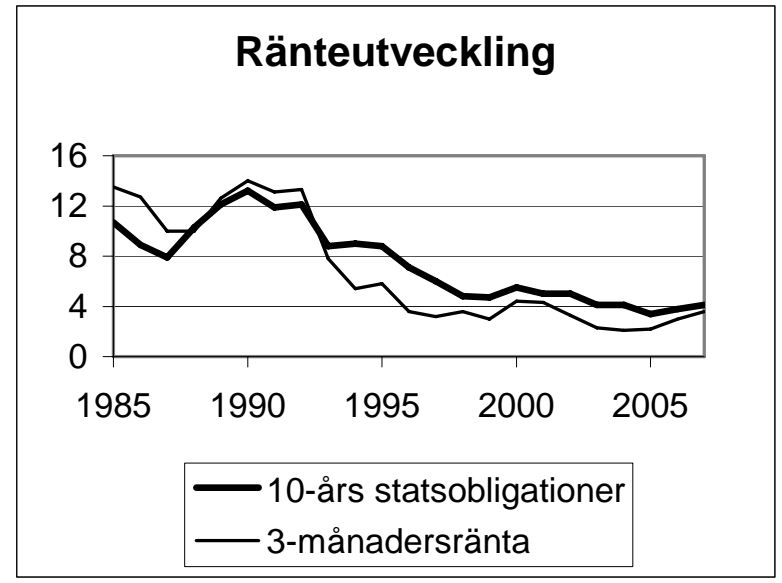

Figur 3.1 Korta och långa nominella räntor. Procent Källa: Finansministeriet.

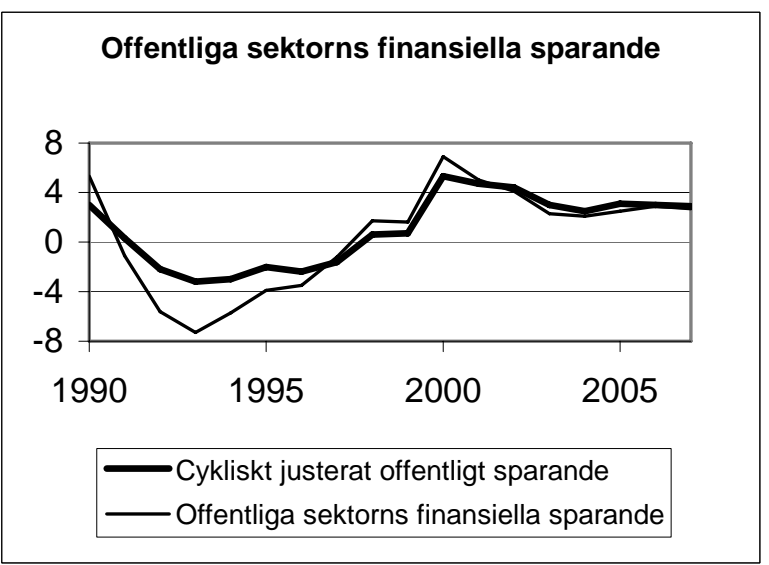

Figur 3.2 Offentligt sparande och cykliskt justerat offentligt sparande. Procent av BNP.

Källa: Finansministeriet.

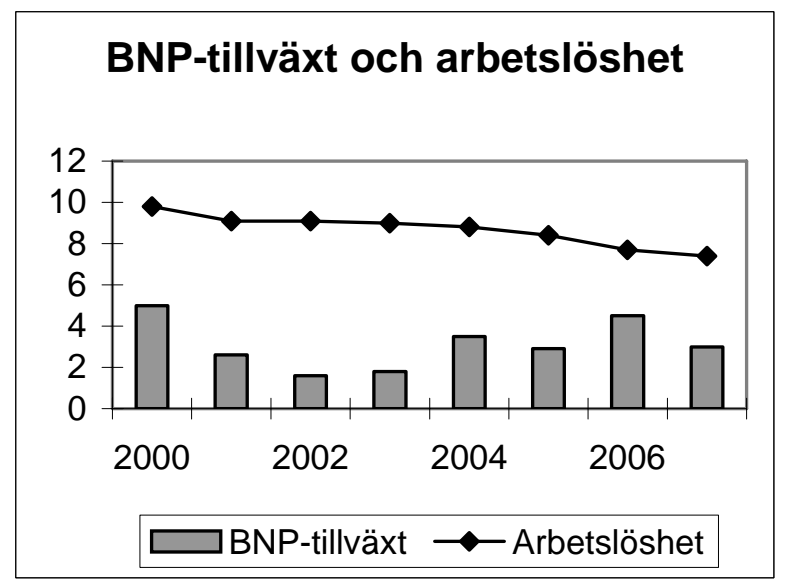

Figur 3.3 BNP-tillväxt och arbetslöshet. Procentuell förändring från föregående år och procent av arbetskraften.

Källa: Finansministeriet. 


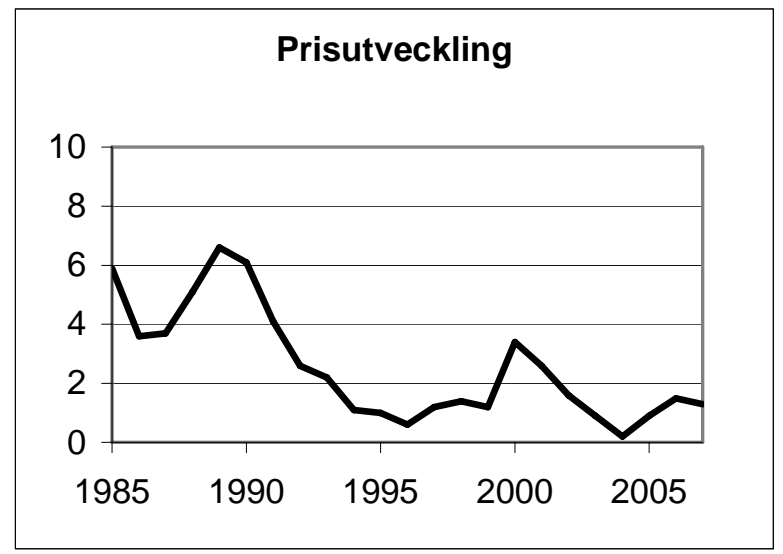

Figur 3.4 Konsument prisindex.

Källa: Finansministeriet.

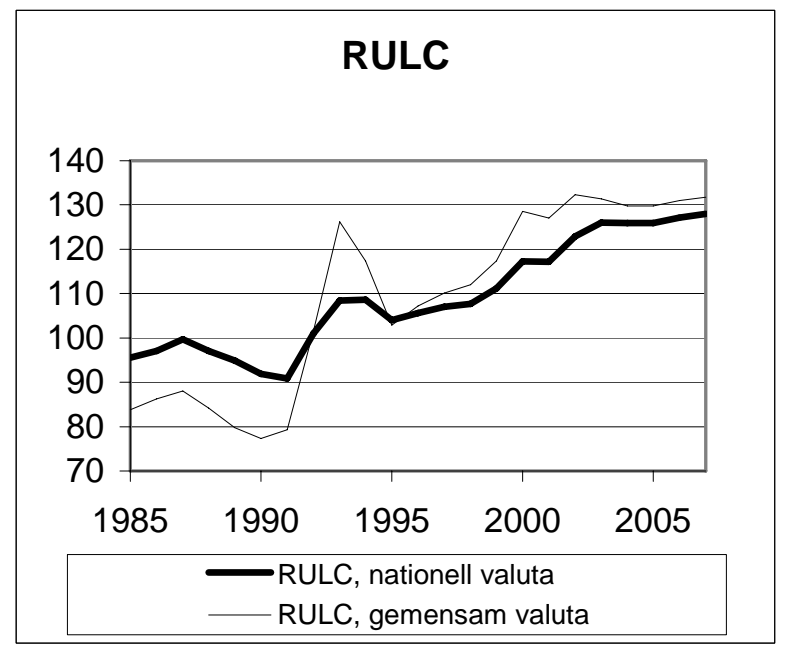

Figur 3.5 Relativ lönekostnad per producerad enhet. Basår 2000. Källa: Finansministeriet.

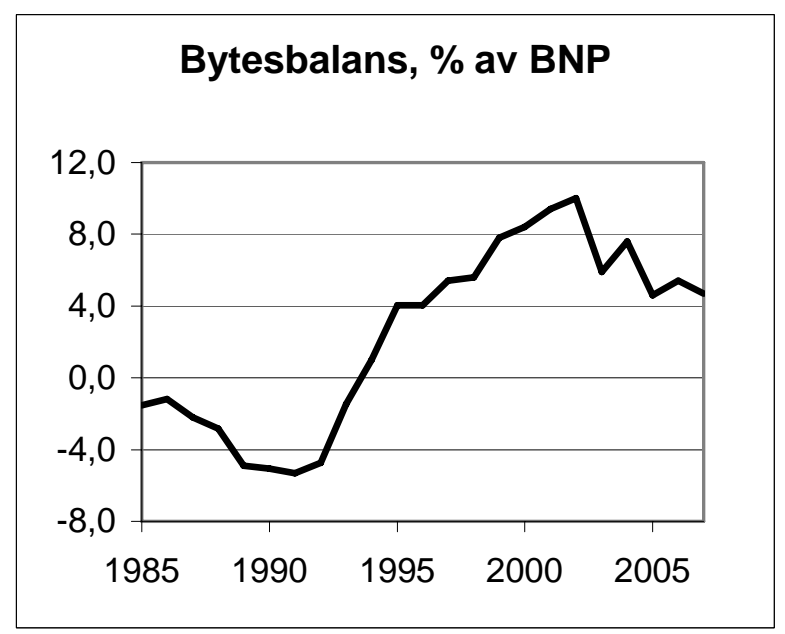

Figur 3.6 Bytesbalans. Procent av BNP.

Källa: Finansministeriet. 


\section{Island}

\subsection{Den ekonomiska politiken}

Den ekonomiska politikens främsta mål är att bibehålla makroekonomisk stabilitet och därmed skapa sunda förutsättningar för ekonomisk tillväxt. Regeringens riktning angående finans- och penningpolitiken har siktat på att uppnå denna huvudmålsättning utan att begränsa näringslivets svängrum för konkurrensmässiga ekonomiska aktiviteter. Kraftig ekonomisk tillväxt har kännetecknat utvecklingen de sista åren. Detta är ett resultat av den aktuella ekonomiska politiken som har inneburit att begränsa statens påverkan på ekonomin med införandet av privatisering, ökat liberalisering och sänkning av skatter för företag och hushåll.

Finanspolitiken förväntas att bli stram på utgiftssidan nästa år. Statsbudgetens överskott vid högkonjunkturen 1997-2001 har använts för att minska statsskulden som i sin tur ger möjligheter till skattesänkningar i framtiden. Enligt budgetpropositionen för året 2007 skall den leda till ett överskott på 15 mdr. IKR eller 1,3 \% av BNP trots att hushållens inkomstskatt kommer att minska med $1 \%$ och individuella skatteavdrag kommer att ökas. Enligt regeringens beslut kommer hushållens skatter över perioden 2005-2007 att minska totalt omkring 20 mdr IKR. En annan viktig del av den ekonomiska politiken har varit privatisering av statliga verksamheter som har pågått de sista åren. I stort sätt har statliga verksamheter tillbakadragits på den finansiella marknaden. För ett år sedan blev statens andel i landets största telefonföretag privatiserat. OECD har föreslagit att energisektorn också skall privatiseras. Inga offentliga beslut har gjorts i detta sammanhang.

Förutom förändringar av statens skattesatser har regeringen också beslutat att uppskjuta olika offentliga investeringsprojekt samt att förminska den reala tillväxten i offentliga konsumtionsutgifterna under nästa år. Under året 2008 förväntas att offentliga investeringsprojekt kommer att ökas igen. Dessa beslut har gjorts med hänsyn till att stora privata investeringar inom energi- och aluminiumsektorn kommer att minskas nästa år. Ökade offentliga investeringar kommer så att påverka ekonomin i viss mån som en kontracyklisk åtgärd.

Statens finansiella sparande förväntas bli omkring $4 \%$ av BNP året 2006. Under nästa år förväntas att statens netto skulder kommer att minskas från 17,4 \% av BNP året 2004 till 4,5 \% året 2006.

Penningpolitiken har sedan våren 2001 kännetecknas av den nya ställningen som Centralbanken fick genom en förändring i vederbörande lagstiftning som innebär full självständighet och uppgiften att uppnå en bestämd prisstabilitet. Målsättningen är att inflationen skall vara omkring 
21/2\% på årsbasis med en toleransintervall på (+/-) 11/2 procentenheter. Inflationen har nu börjat gå uppåt och Centralbanken har från mitten av 2004 systematiskt höjt styrräntan från 5,3 \% till $14 \%$ för att begränsa denna utveckling. Centralbanken har inte uteslutit att höja styrräntan ytterligare om inflationstrycket kommer att fortsätta. Många aktörer på marknaden förväntar då att Centralbanken kommer att börja nedtrappning av styrräntan under första halvåret 2007.

\subsection{Den ekonomiska utvecklingen}

Den ekonomiska tillväxten tog fart igen 2003 efter en lindrig recession 2002. Ett relativt stort investeringsprojekt har pågått sedan första halvåret 2003. Detta projekt innehåller ett utbyggande av aluminium smältverk med produktionskapacitet på 346 tusen ton per år. I tillägg med aluminiumsmältverket görs tillhörande investeringar i vattenkraftsanläggningar. Projektet kommer att pågå till året 2008. Ett annat likartat projekt har börjat med en utvidgning av ett aluminiumsmältverk på västra delen av landet. Denna utvidgning medger en ökning av produktionskapaciteten på 160 tusen ton per år. Ökad efterfrågan på energi i detta sammanhang kommer att försörjas genom investeringar i geothermala kraftanläggningar. Största insatserna i båda projekten kommer att göras under åren 2005 och 2006. Den totala investeringssumman antas uppgå till 300 miljarder IKR som är en knapp tredjedel av BNP året 2005. Dessa stora projekt har bidragit kraftigt till den ekonomiska tillväxten under åren 2003-2006. Under dessa år har inflationen ökat och krävt större instanser från både finans- och penningpolitiken för att undvika högre inflation. Kapitalinflöden i samband med de stora investeringsprojekten samt annan utländsk efterfråga efter IKR har verkat kraftigt för appreciering av den inhemska växelkursen under åren 2004 och 2005. Denna utveckling har bidragit till en ökad importbenägenhet av konsumtions- och investeringsvaror.

Under andra halvåret 2004 uppstod stora oförväntade förändringar på bolånemarknaden. De privata affärsbankerna började konkurrera med den statliga bostadslånefonden. Följden blev att räntan på denna marknad drevs ner och lånens storlek som en andel av bostädernas marknadsvärde ökades. Denna utveckling ledde till att hushållen hade det lättare att ta större lån till en lägre ränta. Följden blev att huspriserna steg snabbt och den inhemska efterfrågan ökade markant. I sammanhang med en starkare krona plus stora pågående investeringsprojekt har underskottet i bytesbalansen ökat mycket under åren 2005 och 2006. Under nästa år förväntas underskottet att minskas parallellt med en mindre inhemsk efterfrågan och svagare krona.

Enligt finansdepartementets prognoser blir tillväxten 4,2 \% året 2006. Nästa år förväntas tillväxten bli $1 \%$ och $2 \frac{1}{2} \%$ året 2008. Efterfrågan på arbetskraft har ökat och arbetslösheten beräknas gå ner till 1,3 \% av ar- 
betsstyrkan under året 2006. På samma tid beräknas inflationen att bli lite över $7 \%$ men kommer att gå ner nästa år. Centralbankens inflationsmål på 2,5 \% förväntas uppnås under senare halvåret 2007.

Finanspolitiken har haft två mål att uppnå de senaste åren. Det ena är att motverka ekonomins överhettning på grund av de stora aluminiumprojekten och större inhemsk efterfråga än man hade förväntat sig. Det andra är att skapa utrymme för att sänka hushållens skatter på ett belopp omkring 20 miljarder IKR som kommer att realiseras under perioden 20052007. Statens finanser förväntas visa ett positivt finansiellt sparande på 4 \% av BNP året 2006 och 1,5 \% året 2007.

\subsection{Utsikterna på medellång sikt}

Finansdepartementet har gjort prognoser för perioden 2008-2012. I sakens natur är sådana prognoser alltid beroende av en stor ovisshet. Resultatet återspeglar huvudsakligen de förutsättningar och det teoretiska underlag som används för framräkningen. Trots detta kan resultatet ge en föreställning om framtiden och därmed eventuellt bli en vägledning för den ekonomiska politiken.

Prognoserna visar att den årliga ekonomiska tillväxten förväntas bli 2,5\% under perioden 2007-2012 jämfört med 5,5\% under perioden 2003-2006. I slutet av de största insatserna av aluminiumprojekten (2007) kommer tillväxtens hastighet att sakta ner till 1 \% (BNI tillväxten blir 0,8 \%) och arbetslösheten kan gå upp till 3,1 \% av arbetsstyrkan under åren 2008 och 2009. Under perioden 2003-2006 kommer den genomsnittliga bytesbalansen att visa ett relativt stort underskott på $12,5 \%$ av BNP men kommer sedan att falla ner till den genomsnittliga nivån på $4 \%$ under perioden 2007-2012. Detta beror dels på ökning av export på aluminiumprodukter och dels på depreciering av växelkursen. 
Tabell 4.1 Nyckeltal för Islands ekonomi. Procentuell förändring ${ }^{1)}$

\begin{tabular}{|c|c|c|c|c|}
\hline & $\begin{array}{r}\text { Mdr kronor } \\
2005\end{array}$ & 2005 & 2006 & 2007 \\
\hline \multicolumn{5}{|l|}{ Fasta priser } \\
\hline Hushållens konsumtionsutgifter & 603,8 & 12,3 & 4,0 & $-1,8$ \\
\hline Offentliga konsumtionsutgifter & 247,1 & 3,3 & 2,7 & 2,1 \\
\hline Fasta bruttoinvesteringar & 288,0 & 37,6 & 8,3 & $-21,6$ \\
\hline Näringsliv exkl. Bostäder & 199,9 & 60,5 & 9,7 & $-28,2$ \\
\hline Bostäder & 58,4 & 11,9 & 9,2 & $-3,0$ \\
\hline Myndigheter & 29,7 & $-13,1$ & $-19,1$ & 1,6 \\
\hline Lagerinvesteringar ${ }^{2)}$ & $-0,9$ & 0,0 & 0,1 & 0,0 \\
\hline Inhemsk efterfrågan & 1138,0 & 15,8 & 5,2 & $-6,4$ \\
\hline Export & 324,3 & 7,1 & 3,7 & 10,1 \\
\hline Import & 450,1 & 28,9 & 5,2 & $-9,4$ \\
\hline Bruttonationalprodukt & 1012,2 & 7,5 & 4,2 & 1,0 \\
\hline Sysselsättning ${ }^{3)}$ & - & 149,0 & 157,7 & 156,9 \\
\hline Öppen arbetslöshet (andel av arbetskraften) & - & 2,1 & 1,3 & 2,1 \\
\hline Konsumentprisindex & - & 4,0 & 7,3 & 4,5 \\
\hline Lön ${ }^{4)}$ & - & 6,9 & 9,2 & 5,5 \\
\hline Effektiv valutakurs ${ }^{5}$ & - & $-10,2$ & 12,3 & 3,2 \\
\hline Bytesförhållande & - & 0,1 & $-1,1$ & $-0,2$ \\
\hline Bytesbalans (procent av BNP). & - & $-16,1$ & $-18,7$ & $-10,7$ \\
\hline 3 mån. penningmarknadsränta (nivå) & - & 8,9 & 12,5 & 11,2 \\
\hline $\begin{array}{l}\text { 1) Beräknat i fasta 2000-priser. } \\
\text { 2) Förändring i procent av föregående års BNP. } \\
\text { 3) Antal 1000-årsverk. } \\
\text { 4) Timlön. } \\
\text { 5) Positivt tal innebär depreciering. }\end{array}$ & & & & \\
\hline
\end{tabular}

Källor: Statistik Island och Finansdepartementet.

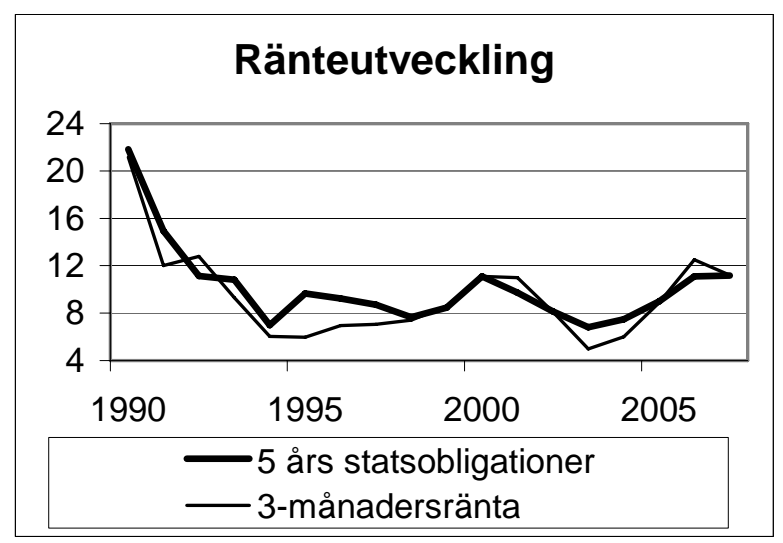

Figur 4.1 Korta och långa nominella räntor. Procent Källa: Finansdepartementet. 


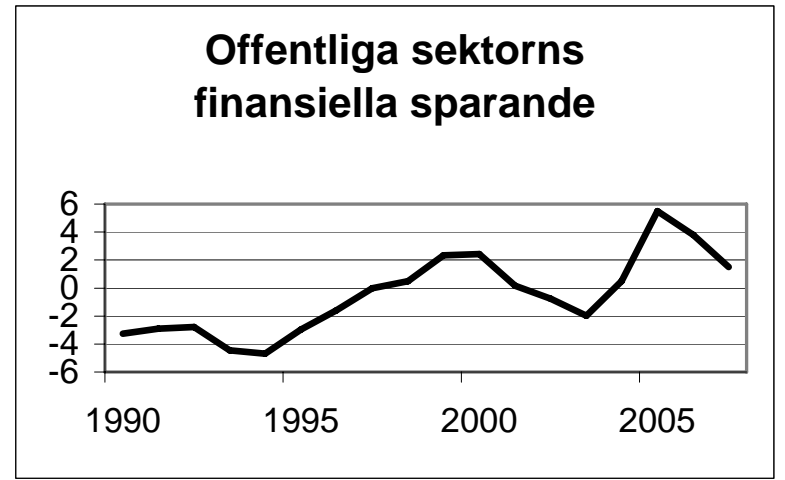

Figur 4.2 Det offentliga finansiella sparandet. Procent av BNP. Källa: Finansdepartementet.

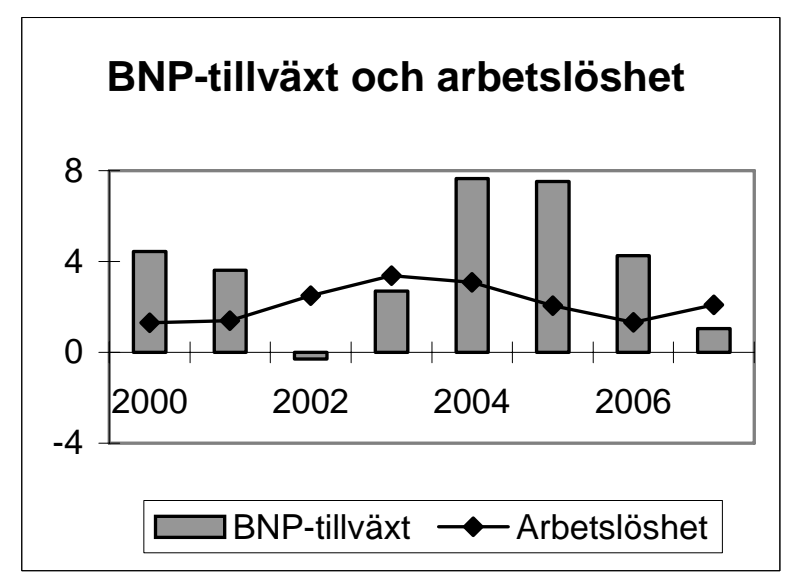

Figur 4.3 BNP-tillväxt och arbetslöshet. Procentuell förändring från föregående år och procent av arbetskraften.

Källa: Finansdepartementet.

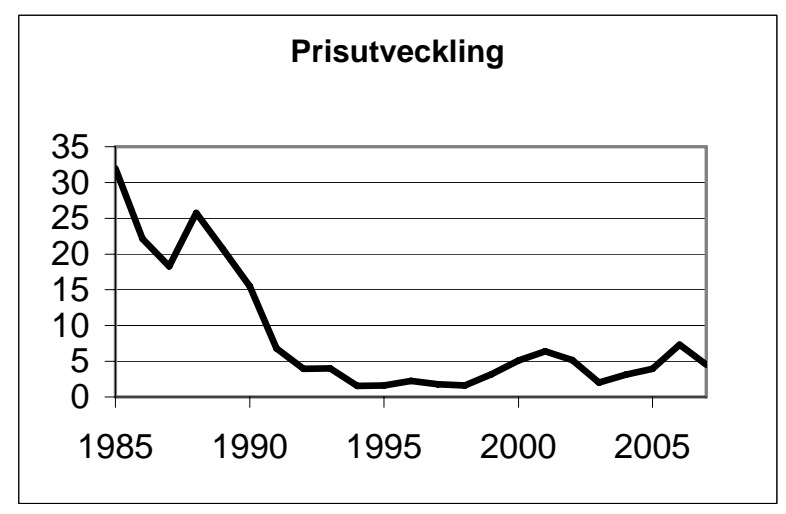

Figur 4.4 Konsumentprisindex.

Källa: Finansministeriet. 


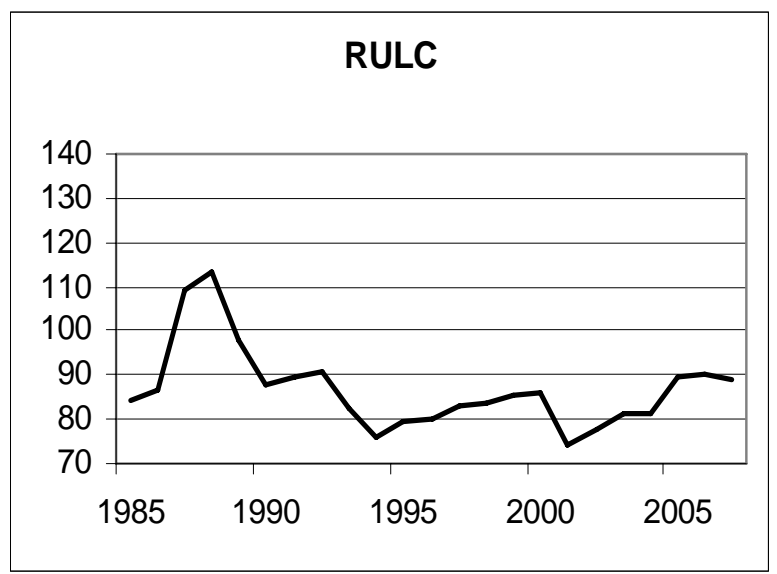

Figur 4.5 Relativ lönekostnad per producerad enhet.

Källa: Finansdepartementet.

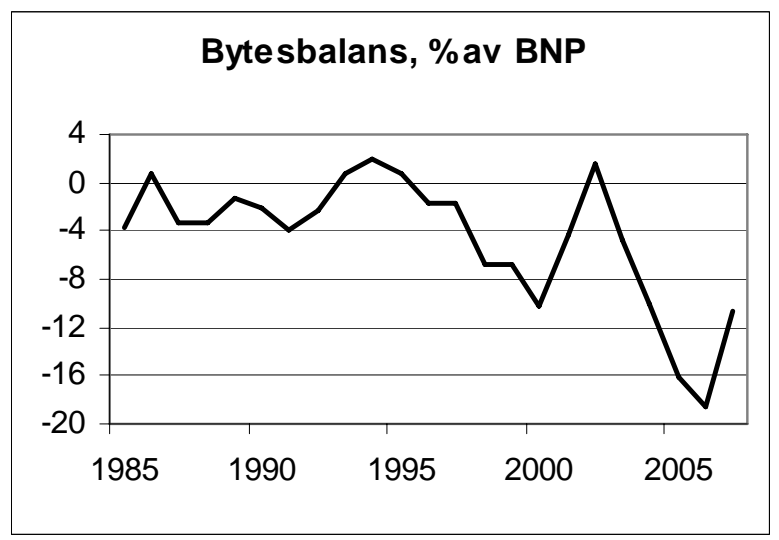

Figur 4.6 Bytesbalans. Procent av BNP.

Källa: Finansdepartementet. 


\section{Norge}

\subsection{Den økonomiske politikken}

Den norske regjeringen vil føre en økonomisk politikk som legger til rette for høy sysselsetting, stabil økonomisk vekst og bærekraftige offentlige velferdsordninger. De ulike delene av den økonomiske politikken må virke sammen for å nå disse målene.

Finanspolitikken er lagt opp med utgangspunkt i retningslinjer som innebærer at petroleumsinntektene gradvis fases inn i norsk økonomi, om lag i takt med utviklingen i forventet realavkastning av Statens pensjonsfond - Utland (handlingsregelen). Budsjettpolitikken er dermed gitt en mellomlangsiktig forankring. Samtidig understreker retningslinjene at hensynet til en stabil økonomisk utvikling skal tillegges betydelig vekt $\mathrm{i}$ den løpende utformingen av budsjettpolitikken.

Pengepolitikken skal sikte mot stabilitet i den norske krones verdi, nasjonalt og i forhold til Norges handelspartnere. Den operative gjennomføringen av pengepolitikken skal rettes inn mot lav og stabil inflasjon, definert som en årsvekst i konsumprisene som over tid er nær 2,5 \%. Av forskriften følger det at pengepolitikken skal bidra til å stabilisere utviklingen i produksjon og sysselsetting og til stabile forventninger om valutakursutviklingen. Budsjett- og pengepolitikken må virke sammen for å bidra til en balansert utvikling i norsk økonomi.

Norsk økonomi er inne i sitt fjerde år med sterkt vekst.. Sysselsettingen øker raskt og arbeidsledigheten nærmer seg det lave nivået fra konjunkturtoppen på slutten av 1990-tallet. Regjeringen legger opp til å holde bruken av oljeinntekter på et nivå som understøtter en fortsatt balansert utvikling i norsk økonomi. I tråd med dette foreslår budsjettet for 2007 et strukturelt, oljekorrigert underskudd på 71 mrd. kroner. Bruken av oljeinntekter er dermed om lag på linje med forventet realavkastning av kapitalen i Statens pensjonsfond - Utland, etter fem år med strukturelle underskudd betydelig over fondsavkastningen. Budsjettforslaget innebærer at bruken av oljeinntekter øker med nærmere 6 mrd. 2007-kroner fra 2006 til 2007, eller med 0,3 prosentpoeng regnet som andel av BNP for Fastlands-Norge. Skatter og avgifter bringes tilbake til nivået fra 2004, som innebærer en skatteøkning på knapt 2 mrd. kroner.

\subsection{Den økonomiske utviklingen}

Etter omslaget i 2003 har veksten i norsk økonomi nå ligget over sitt historiske gjennomsnitt i over tre år. Ordrereservene er store både i indu- 
strien og i bygg og anlegg, og kapasitetsutnyttelsen er høy. Sysselsettingen har økt meget raskt det siste året, og arbeidsledigheten er kommet ned på et lavt nivå. Investeringene i fastlandsøkonomien har tatt seg kraftig opp, og rask økning i foretakssektorens opplåning kan tyde på videre vekst i bedriftsinvesteringene framover.

Også verdensøkonomien er nå inne i en sterk oppgangsperiode. Den relativt høye veksten som forventes hos Norges handelspartnere i 2006 gir positive impulser til industrien og annen eksportrettet virksomhet. Samtidig øker husholdningenes inntekter sterkt, og dette bidrar til å holde forbruksveksten oppe. For inneværende år trekkes aktiviteten i fastlandsøkonomien også opp av ytterligere økning i oljeinvesteringene, som så ventes å falle litt tilbake neste år. Samlet sett anslås BNP for FastlandsNorge å vokse med 31/2\% i 2006. Anslaget trekkes ned av utviklingen innen kraftsektoren, etter at mye nedbør bidro til svært høy elektrisitetsproduksjon i 2005. Utenom elektrisitetsproduksjonen anslås veksten i fastlandsøkonomien til nærmere $4 \%$ i inneværende år, som er klart over resultatet for fjoråret. For 2007 anslås veksten i fastlandsøkonomien til knapt $3 \%$, også når elektrisitetsproduksjonen holdes utenom.

Etter flere år med vekst i fastlandsøkonomien over trend strammes arbeidsmarkedet nå til. Fra sommeren 2005 har sysselsettingen økt kraftig, samtidig som arbeidsledigheten har gått raskt ned. Ifølge Arbeidskraftundersøkelsen (AKU) var det i tremånedersperioden juni-august i år sysselsatt over 70000 flere personer enn for ett år siden. Samtidig var AKUledigheten kommet ned på et nivå tilsvarende 3,4 \% av arbeidsstyrken, det laveste nivået på 5 år. For 2006 sett under ett anslås veksten i sysselsettingen nå til 60000 personer. Som gjennomsnitt for året anslås AKUledigheten til 3,5 \% av arbeidsstyrken. For 2007 anslås ledigheten til 3,3 $\%{ }^{4}$

Lønnsveksten avtok fra 3,5 pst i 2004 til 3,3 \% i 2005. På bakgrunn av de resultatene som så langt foreligger for årets lønnsoppgjør, anslås årslønnsveksten i 2006 nå til 33/4 \%. Anslaget forutsetter at det vises moderasjon i de lokale forhandlingene. Den relativt moderate lønnsveksten så langt i denne konjunkturoppgangen må bl.a. ses i sammenheng med en betydelig tilstrømming av arbeidstakere fra Norden, Polen og de baltiske landene til det norske arbeidsmarkedet. En økende beholdning av ledige stillinger ved arbeidskontorene og tiltakende mangel på kvalifisert arbeidskraft bærer likevel bud om økende press i arbeidsmarkedet, med fare for tiltakende lønns- og kostnadsvekst. For 2007 er lønnsveksten anslått til 4 $1 \frac{1}{2} \%$. Norske lønnskostnader er høye sammenliknet med nivået hos våre handelspartnere. Dette øker isolert sett næringslivets sårbarhet over-

\footnotetext{
${ }^{4}$ Etter ferdigstillelsen av anslagene i Nasjonalbudsjettet for 2007 gjorde Statistisk sentralbyrå oppmerksom på at den løpende statistikken ved en feil har undervurdert nivået på arbeidsledigheten i 2006, og justerte sine tall litt opp. De endrede tallene påvirker ikke det generelle bildet av utviklingen i arbeidsmarkedet eller anslagene for den øvrige utviklingen i norsk økonomi. Anslagene på arbeidsledigheten er imidlertid oppjustert med rundt $1 / 4$ prosentpoeng i denne rapporten sammenlignet med anslagene i Nasjonalbudsjettet for 2007.
} 
for tiltakende lønnsvekst. Både for 2006 og 2007 anslås lønnsveksten å ligge klart høyere i Norge enn hos våre viktigste handelspartnere. Dersom prisene på norske eksportprodukter skulle falle vesentlig tilbake eller kronen styrke seg igjen, kan lønnsomheten i næringslivet raskt komme under press. Dette kan få negative følger for produksjon og sysselsetting, slik en så i 2002 og 2003.

Konsumprisene (KPI) økte med 1,6 \% fra 2004 til 2005. Justert for avgiftsendringer og utenom energivarer (KPI-JAE) økte prisene med $1,0 \%$. For 2006 anslås det at KPI og KPI-JAE vil øke med henholdsvis $2 \frac{1}{2} \%$ og $1 \%$. Den lave veksten i KPI-JAE har bl.a. bakgrunn i fortsatt prisfall på importerte konsumvarer. For 2007 legges det til grunn at KPIJAE vil øke med $1 \frac{1}{2} \%$. Utviklingen i elektrisitetsprisene og det foreslåtte avgiftsopplegget som medfører en økning i satsen for merverdiavgift på mat fra $13 \%$ til $14 \%$, bidrar til at veksten i KPI neste år anslås til 13/4 \%. Svekkelsen av norske kroner gjennom sommermånedene øker usikkerheten rundt anslaget for prisveksten framover.

\subsection{Utsiktene på mellomlang sikt}

På mellomlang sikt bestemmes produksjonskapasiteten i økonomien av produktivitetsutviklingen og tilgangen på arbeidskraft og kapital. Med en gjennomsnittlig timeverksproduktivitet i fastlandsøkonomien på rundt 2 $\%$ og en gjennomsnittlig timeverksvekst på knapt $1 \frac{2}{2} \%$, kan trendveksten i produksjonskapasiteten for Fastlands-Norge i årene fram mot 2010 anslås til 21/4-21/2\%.

Siden sommeren 2003 har veksten i fastlandsøkonomien vært klart sterkere enn den anslåtte trendveksten, og for 2006 og 2007 anslås veksten i BNP for Fastlands-Norge til henholdsvis 3,4 \% og 2,9 \%. Nedgangen i veksttakten i 2007 må ses i sammenheng med at de siste årenes sterke vekst i oljeinvesteringene snus til en svak nedgang, samtidig som veksten i husholdningenes etterspørsel er ventet å avta blant annet som følge av noe høyere renter. Utviklingen etter 2007 ventes blant annet å bli påvirket av følgende forhold:

En nedgang i oljeinvesteringene i årene 2008-2010 ventes isolert sett å bidra til svakere vekst i norsk økonomi. I beregningene er det imidlertid lagt til grunn at nedgangen i petroleumsinvesteringene i noen grad blir motvirket av at leverandørindustrien klarer å omstille produksjonen til andre produkter og andre markeder.

En gradvis økning i pengemarkedsrentene framover, i tråd med forventningene i terminmarkedet, innebærer at pengepolitikken gradvis vil bli mindre ekspansiv. Med en relativt stabil valutakurs ventes dette å redusere veksten i både husholdningenes etterspørsel og bedriftenes investeringer. 
I tillegg til disse forholdene, vil veksten i norsk økonomi også avhenge av impulsene fra budsjettpolitikken. I anslagene som gjengis her, er det teknisk lagt til grunn om lag samme impulser fra budsjettpolitikken i årene framover som anslått for 2007. Med disse forutsetningene kan veksten i fastlandsøkonomien i årene 2008-2010 bli noe svakere enn trendveksten, og kapasitetsutnyttingen vil utvikle seg i retning av et normalnivå. Dette vil dempe presset på arbeidskraftressursene, og ledigheten vil kunne holde seg i området 3-31/2\%. Eventuell raskere innfasing av oljeinntektene vil kunne gi sterkere vekst og lavere ledighet, men også innebære en risiko for at lønnsveksten øker kraftig, slik vi opplevde på slutten av 1990-tallet. Det knytter seg betydelig usikkerhet til denne typen framskrivinger.

Tabell 5.1 Nyckeltal för Norges ekonomi. Procentuell förändring ${ }^{1)}$.

\begin{tabular}{|c|c|c|c|c|}
\hline & $\begin{array}{r}\text { Mdr. kronor } \\
2005\end{array}$ & 2005 & 2006 & 2007 \\
\hline \multicolumn{5}{|l|}{ Fasta priser } \\
\hline Hushållens konsumtion & 795,7 & 3,4 & 3,7 & 3,0 \\
\hline Offentlig konsumtion & 387,5 & 1,5 & 2,7 & 2,7 \\
\hline Fasta bruttoinvesteringar & 356,3 & 10,9 & 8,2 & 1,8 \\
\hline \multicolumn{5}{|l|}{ Varav: } \\
\hline Oljeverksamhet & 88,2 & 15,6 & 5,0 & $-2,5$ \\
\hline Företag & 121,7 & 9,8 & 7,1 & 6,1 \\
\hline Bostäder & 79,5 & 14,5 & 8,4 & 0,0 \\
\hline Myndigheter & 50,8 & $-0,8$ & 16,1 & 0,2 \\
\hline Lagerinvesteringar $^{2)}$ & 36,3 & 0,2 & $-0,1$ & 0,2 \\
\hline Total inhemsk efterfrågan & 1575,8 & 4,6 & 4,3 & 2,8 \\
\hline Export & 862,2 & 0,7 & 1,8 & 5,3 \\
\hline Import & 534,2 & 7,4 & 7,4 & 3,5 \\
\hline Bruttonationalprodukt & 1903,8 & 2,3 & 2,4 & 3,6 \\
\hline Varav: Fastlands-Norge & 1410,3 & 3,7 & 3,4 & 2,9 \\
\hline Sysselsättning, personer & - & 0,7 & 2,6 & 1,3 \\
\hline Arbetslöshet (\% av arbetskraften) & - & 4,6 & 3,5 & 3,3 \\
\hline Konsumtionsprisindex & - & 1,6 & $21 / 2$ & $13 / 4$ \\
\hline Lön ${ }^{3)}$ & - & 3,3 & $33 / 4$ & $41 / 2$ \\
\hline Effektiv valutakurs ${ }^{4)}$ & - & $-4,4$ & $-0,6$ & 0,9 \\
\hline Bytesförhållande & - & 15,0 & 9,4 & $-4,8$ \\
\hline Bytesbalans (\% av BNP). & - & 16,6 & 17,8 & 16,9 \\
\hline 3-månaders penningmarknadsränta (nivå) & - & 2,2 & 3,1 & 4,1 \\
\hline
\end{tabular}

1) Beräknat i fasta priser, basår 2003.

2) Förändring $i \%$ av föregående års BNP.

3) Årslön.

4) Positivt tal innebär depreciering

Källor: Statistisk sentralbyrå og Finansdepartementet. 


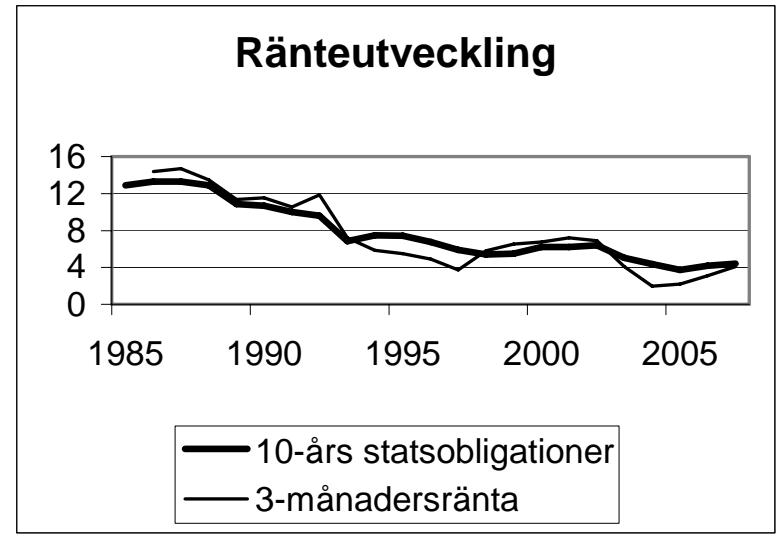

Figur 5.1 Korta och långa nominella räntor. Procent. Källa: Statistisk sentralbyrå og Finansdep.

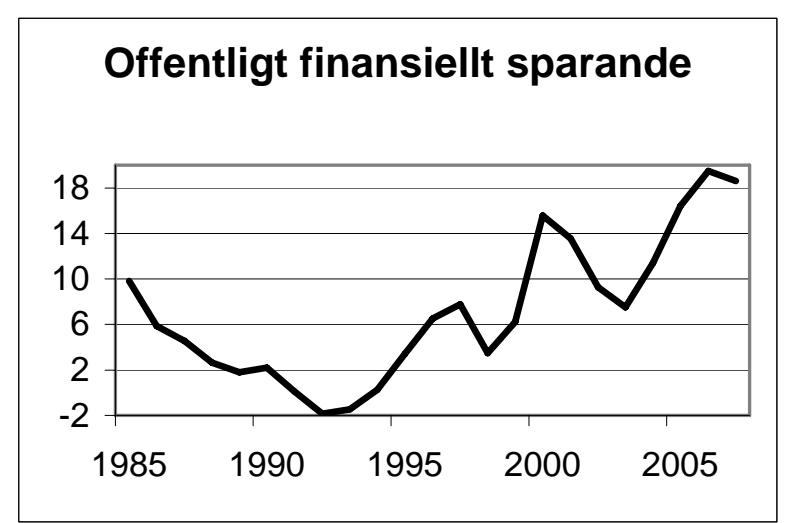

Figur 5.2 Det offentliga finansiella sparandet. Procent av BNP. Källa: Finansdepartementet.

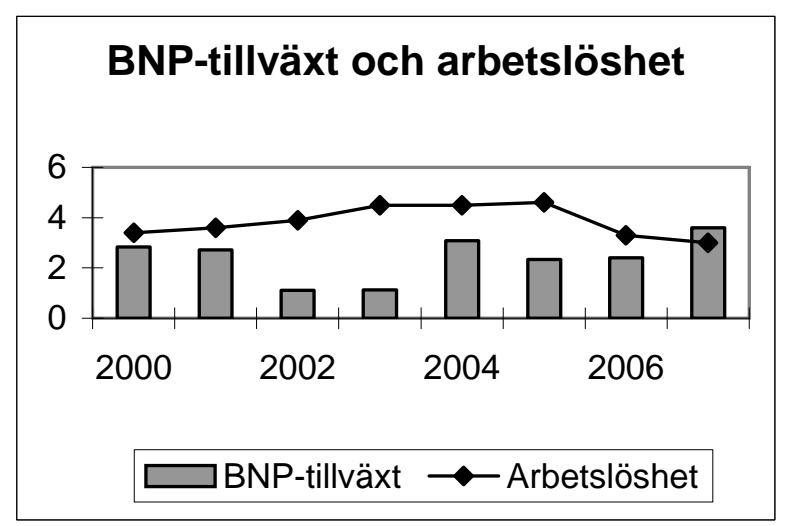

Figur 5.3 BNP-tillväxt och arbetslöshet. Procentuell förändring från föregående år och procent av arbetskraften.

Källa: Finansdepartementet. 


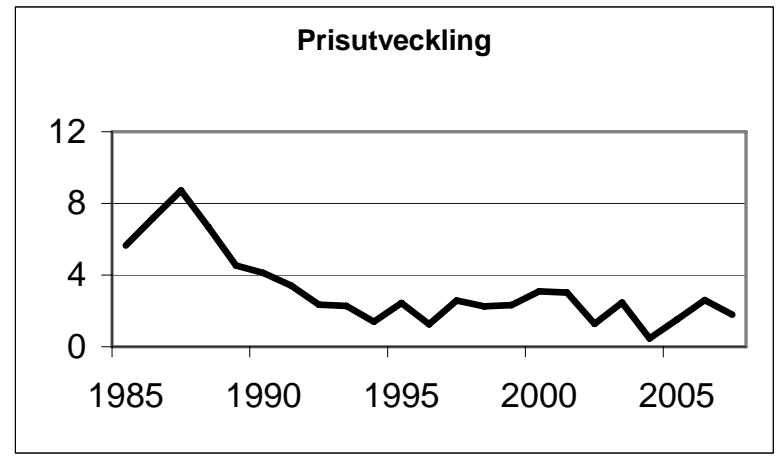

Figur 5.4 Konsumentprisindex.

Källa: Finansdepartementet.

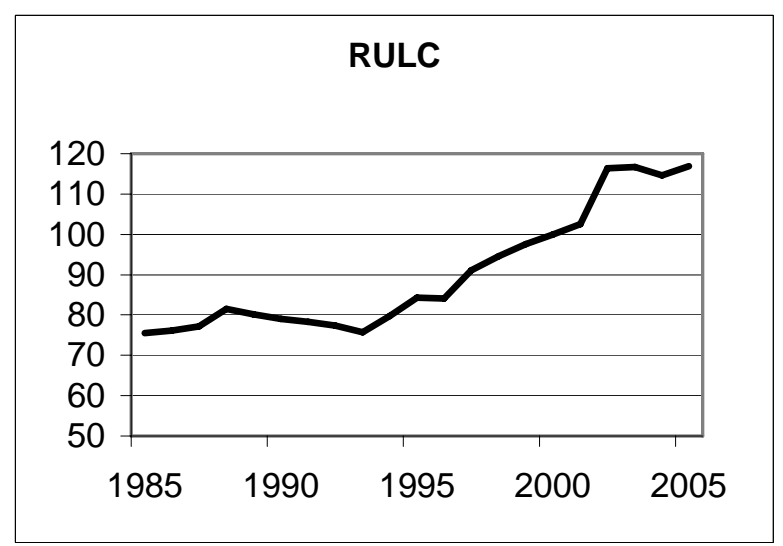

Figur 5.5 Relativ lönekostnad per producerad enhet. Basår 2000. Källa: OECD.

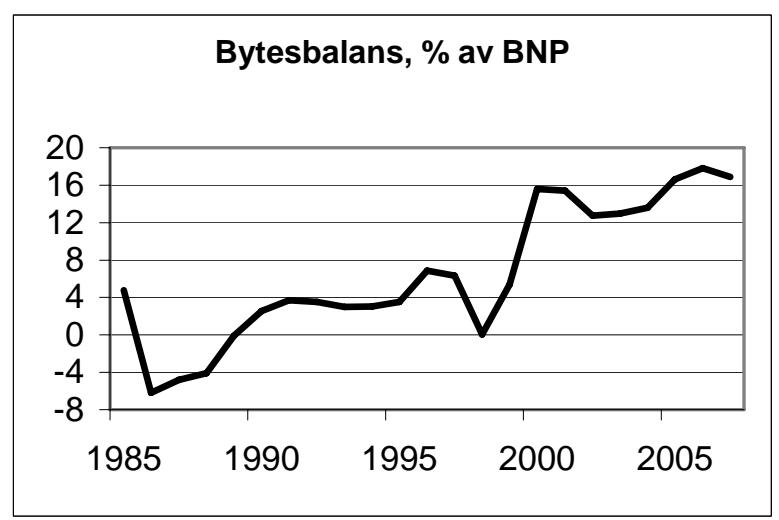

Figur 5.6 Bytesbalans. Procent av BNP.

Källa: Statistisk sentralbyrå og Finansdep. 


\section{Sverige}

\section{1 Den ekonomiska politiken}

Finanspolitikens främsta uppgift är att lägga grunden för uthålligt hög tillväxt och full sysselsättning genom att upprätthålla sunda offentliga finanser. Två övergripande budgetpolitiska mål styr regeringens budgetpolitik: överskottsmålet för de offentliga finanserna och utgiftstaket för staten.

Sedan år 2000 gäller ett mål att den offentliga sektorns finansiella sparande ska uppgå till $2 \%$ av BNP i genomsnitt över en konjunkturcykel. Detta överskottsmål motiveras i första hand av behovet att stärka den offentliga sektorns finansiella ställning inför de framtida demografiska påfrestningarna på de offentliga välfärdssystemen. Samtidigt innebär målet att det skapas en buffert för att undvika alltför stora underskott i en lågkonjunktur. Med utgångspunkt från det övergripande målet anger regeringen i budgetpropositionen preciserade överskottsmål för nästkommande budgetår. Det preciserade överskottsmålet bestäms med hänsyn till konjunkturläge och resursutnyttjande i svensk ekonomi.

Den offentliga sektorns finansiella sparande uppgick till 2,8\% av BNP 2005 och beräknas vara oförändrat i år. Därmed uppgår genomsnittet perioden 2000-2006 till 2,0 \% av BNP. Under perioden 2007-2009 minskar såväl inkomster som utgifter uttryckta som andel av BNP. Det finansiella sparandet beräknas till 2,3 \% BNP 2007 för att sedan förstärkas under 2008 och 2009. Överskotten medför att den finansiella ställningen fortsätter att stärkas under prognosperioden. Därtill kommer att statsskulden och den konsoliderade bruttoskulden minskar kraftigt till följd av planerade försäljningar av statens aktieinnehav.

Budgetpolitikens främsta styrinstrument är utgiftstaken. Utgiftstaken fastställs normalt för tre år framåt. Utgiftstaken förhindrar att tillfälligt högre inkomster används för varaktigt högre utgifter. Utgiftstaket har sedan det infördes 1997 klarats samtliga år, även om marginalen varit knapp. I budgetpropositionen för 2007 föreslås att utgiftstaken för 2007 och 2008 sänks med 11 miljarder kronor jämfört med tidigare beslutade utgiftstak.

Stabila priser är en förutsättning för en ekonomisk politik för hög tillväxt och full sysselsättning. Riksdagen har lagt fast att den övergripande uppgiften för penningpolitiken är prisstabilitet. Riksbanken bedriver på denna grund penningpolitiken självständigt. Riksbanken definierar prisstabilitet som att ökningen av konsumentprisindex skall begränsas till 2 \% med en tolerans på 1 procentenhet uppåt och nedåt. Regeringen stöder penningpolitikens inriktning och står bakom inflationsmålet. 


\section{2 Den ekonomiska utvecklingen}

Den svenska BNP-tillväxten väntas bli stark 2006. Bakgrunden till den positiva utvecklingen är att efterfrågan växer på bred front. Nästa år förväntas BNP-tillväxten bli fortsatt hög men lägre jämfört med 2006 till följd av en inbromsning i export- och investeringstillväxten. Exporttillväxten dämpas då den globala konjunkturen mattas. Den under flera år starka investeringstillväxten avtar i takt med att den utökade produktionskapaciteten tas i bruk. Inbromsningen i export- och investeringstillväxten motverkas i viss utsträckning av en tilltagande konsumtion i hushållen. Hushållskonsumtionen väntas växa kraftigt 2007, bl.a. som en följd av en stark sysselsättningsutveckling, föreslagna inkomstskattesänkningar och en i utgångsläget god förmögenhetsställning. Den offentliga konsumtionen stiger främst inom kommunsektorn och gynnas av starka kommunfinanser.

Sysselsättningen vände uppåt hösten 2005. Efterfrågan är stark, antalet lediga jobb och företagens anställningsplaner är positiva och sysselsättningen väntas därför fortsätta att stiga framöver. Många som har stått utanför arbetskraften har sökt sig till arbetsmarknaden. Den öppna arbetslösheten har därför inte sjunkit i motsvarande grad. Det högre arbetskraftsutbudet gynnar en varaktigt högre sysselsättning och motverkar arbetskraftsbrist. De reformer som föreslås av den nya regeringen har en positiv effekt på såväl sysselsättning, arbetskraftsutbud som arbetslöshet. Den öppna arbetslösheten bedöms stiga något under 2007 när antalet arbetsmarknadspolitiska program minskas. Den totala arbetslösheten, dvs. öppen arbetslöshet och personer i arbetsmarknadspolitiska program minskar dock markant.

\section{3 Utsikterna på medellång sikt}

På längre sikt är det svårt att förutsäga konjunktursvängningar. Beräkningarna för 2008 och 2009 grundar sig därför på bedömningar om hur stort resursutnyttjandet är samt på den potentiella tillväxttakten i ekonomin. Det bedöms fortfarande finnas lediga resurser på arbetsmarknaden 2007 vilket innebär att BNP kan öka i god takt även 2008 och 2009 utan risk för alltför hög inflation. BNP växer med 3,1 \% 2008 och 2,7 \% 2009. Den öppna arbetslösheten sjunker till 4,3\% 2009 och den s.k. totala arbetslösheten, dvs. öppen arbetslöshet inklusive andelen deltagare i arbetsmarknadspolitiska program, faller till 5,8\%. 
Tabell 6.1 Nyckeltal för Sveriges ekonomi. Procentuell förändring ${ }^{1)}$.

\begin{tabular}{|c|c|c|c|c|}
\hline & $\begin{array}{r}\text { Mdr. kronor } \\
2005\end{array}$ & 2005 & 2006 & 2007 \\
\hline \multicolumn{5}{|l|}{ Fasta priser } \\
\hline Hushållens konsumtion & 1283 & 2,4 & 3,6 & 4,2 \\
\hline Offentlig konsumtion & 728 & 0,7 & 1,4 & 1,5 \\
\hline Fasta bruttoinvesteringar & 455 & 8,5 & 7,2 & 3,3 \\
\hline Företag & 307 & 8,9 & 7,4 & 3,0 \\
\hline Bostäder & 75 & 16,9 & 8,7 & 2,9 \\
\hline Myndigheter & 73 & $-0,5$ & 5,0 & 5,0 \\
\hline Lagerinvesteringar $^{1)}$ & 2 & $-0,2$ & $-0,2$ & 0,1 \\
\hline Total inhemsk efterfrågan & 2467 & 2,7 & 3,4 & 3,4 \\
\hline Export & 1299 & 6,4 & 8,3 & 6,4 \\
\hline Import & 1093 & 7,3 & 7,6 & 7,1 \\
\hline Bruttonationalprodukt & 2673 & 2,7 & 4,0 & 3,3 \\
\hline Sysselsättning, personer & - & 0,8 & 1,7 & 1,5 \\
\hline Arbetslöshet (\% av arbetskraften) & - & 6,0 & 5,6 & 5,8 \\
\hline Konsumtionsprisindex & - & 0,5 & 1,6 & 2,5 \\
\hline Lön ${ }^{2)}$ & - & 3,1 & 3,2 & 3,7 \\
\hline Effektiv valutakurs ${ }^{3)}$ & - & 2,0 & $-0,6$ & $-3,1$ \\
\hline Bytesförhållande & - & $-1,4$ & $-0,5$ & 1,7 \\
\hline Bytesbalans (\% av BNP). & - & 6,4 & 6,8 & 7,7 \\
\hline 6-månaders statsskuldväxel (nivå) & - & 1,8 & 2,5 & 3,5 \\
\hline
\end{tabular}

Beräknat i fasta priser, basår 2005 .

2) Förändring i \% av föregående års BNP.

3) Nominell timlön.

4) Positivt tal innebär depreciering

Källor: Finansdepartementet, Medlingsinstitutet, Statistiska centralbyrån.

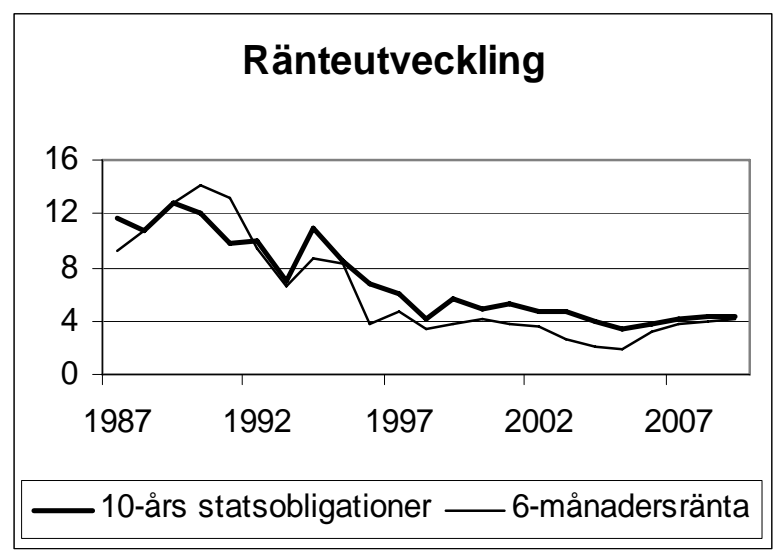

Figur 6.1 Korta och långa nominella räntor. Procent.

Källa: Finansdepartementet. 


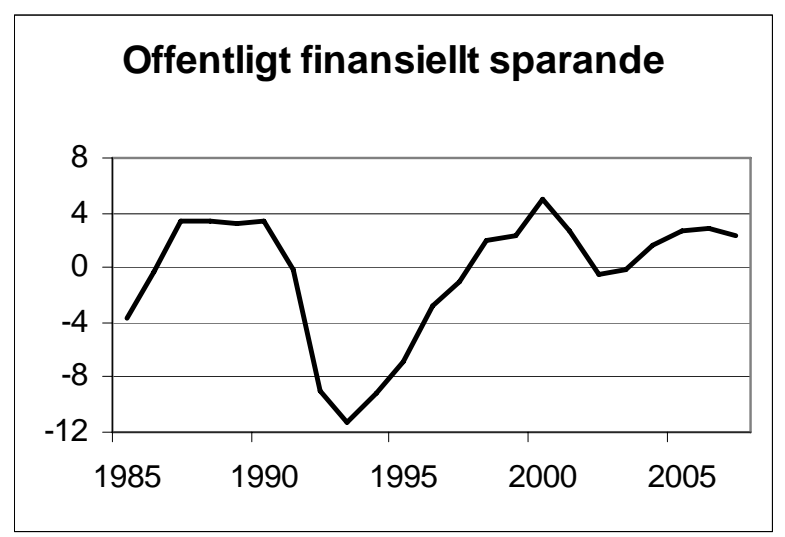

Figur 6.2 Relativ lönekostnad per producerad enhet. Basår 2000. Källa: $\mathrm{OECD}$.

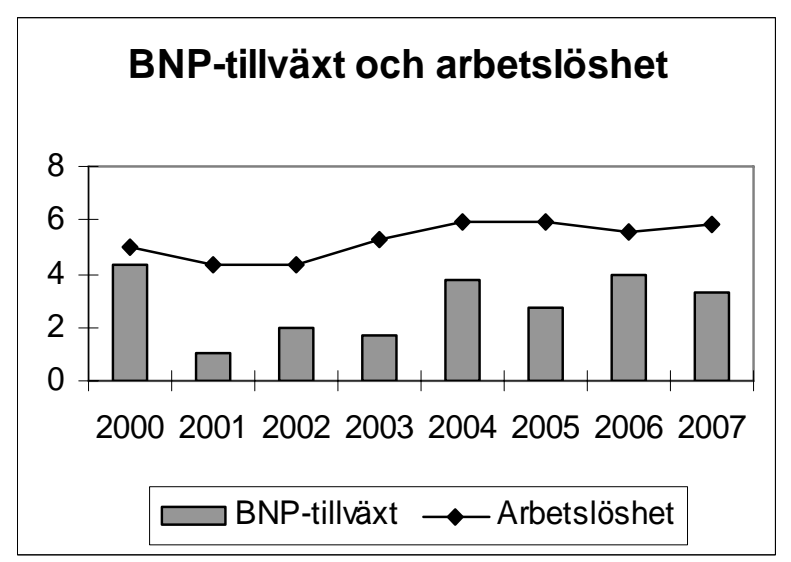

Figur 6.3 BNP-tillväxt och arbetslöshet. Procentuell förändring från föregående år och procent av arbetskraften.

Källa: Finansdepartementet.

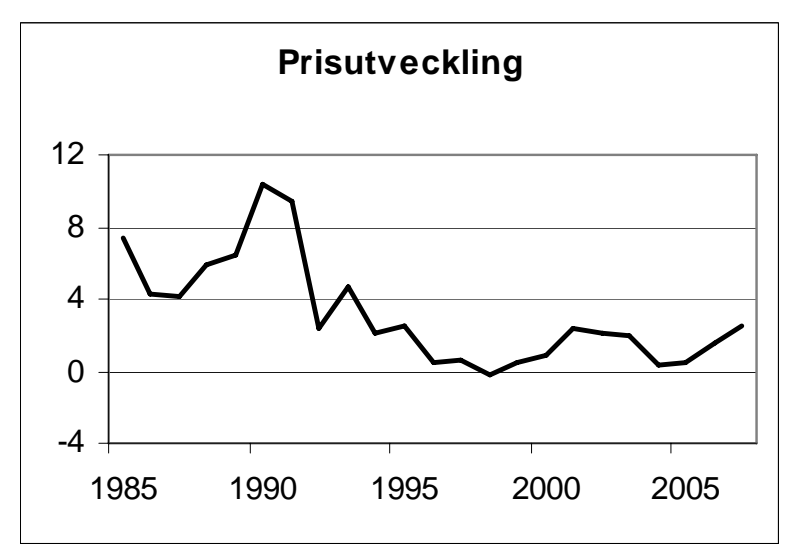

Figur6.4 Relativ lönekostnad per producerad enhet. Basår 2000. Källa: $\mathrm{OECD}$ 


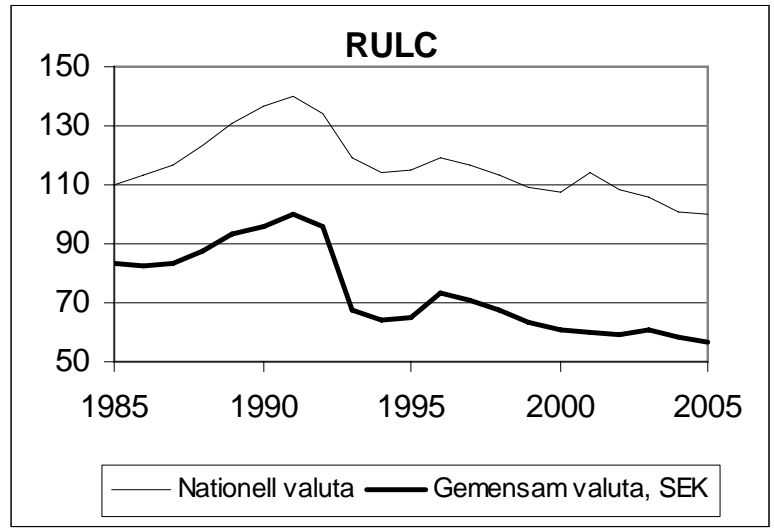

Figur 6.5 Relativ lönekostnad per producerad enhet. Basår 1980. Källor: Konjunkturinstitutet, Statistiska centralbyrån och Finansdepartementet.

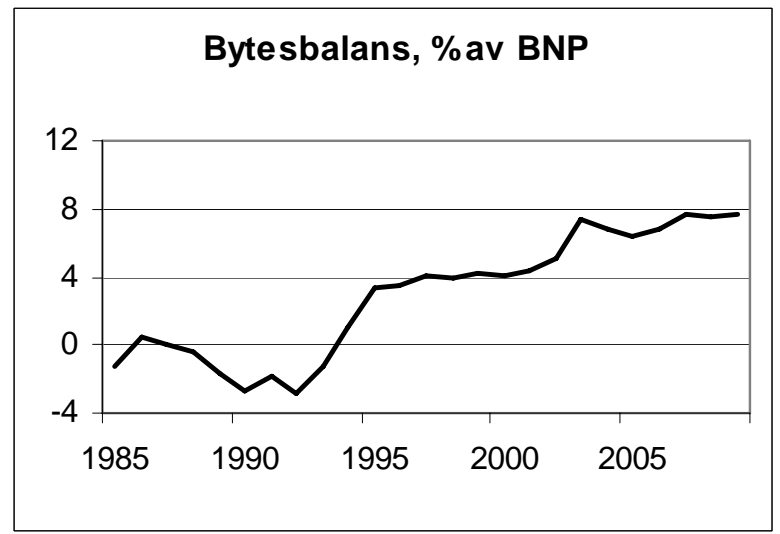

Figur 6.6 Relativ lönekostnad per producerad enhet. Basår 2000. Källa: OECD. 